Review

\title{
Bioactive Secondary Metabolites from Octocoral-Associated Microbes-New Chances for Blue Growth
}

\author{
Inês Raimundo ${ }^{\dagger}$, Sandra G. Silva ${ }^{+}{ }^{+}$, Rodrigo Costa $*$ i) and Tina Keller-Costa *(i) \\ Institute for Bioengineering and Biosciences (iBB), Instituto Superior Técnico (IST), Universidade de Lisboa, \\ 1049-001 Lisbon, Portugal; nex_raimundo@hotmail.com (I.R.); sandragodinhosilva@tecnico.ulisboa.pt (S.G.S.) \\ * Correspondence: rodrigoscosta@tecnico.ulisboa.pt (R.C.); tinakellercosta@tecnico.ulisboa.pt (T.K.-C.) \\ t These authors contributed equally to this work.
}

Received: 4 November 2018; Accepted: 29 November 2018; Published: 4 December 2018

\begin{abstract}
Octocorals (Cnidaria, Anthozoa Octocorallia) are magnificent repositories of natural products with fascinating and unusual chemical structures and bioactivities of interest to medicine and biotechnology. However, mechanistic understanding of the contribution of microbial symbionts to the chemical diversity of octocorals is yet to be achieved. This review inventories the natural products so-far described for octocoral-derived bacteria and fungi, uncovering a true chemical arsenal of terpenes, steroids, alkaloids, and polyketides with antibacterial, antifungal, antiviral, antifouling, anticancer, anti-inflammatory, and antimalarial activities of enormous potential for blue growth. Genome mining of 15 bacterial associates (spanning 12 genera) cultivated from Eunicella spp. resulted in the identification of 440 putative and classifiable secondary metabolite biosynthetic gene clusters (BGCs), encompassing varied terpene-, polyketide-, bacteriocin-, and nonribosomal peptide-synthase BGCs. This points towards a widespread yet uncharted capacity of octocoral-associated bacteria to synthetize a broad range of natural products. However, to extend our knowledge and foster the near-future laboratory production of bioactive compounds from (cultivatable and currently uncultivatable) octocoral symbionts, optimal blending between targeted metagenomics, DNA recombinant technologies, improved symbiont cultivation, functional genomics, and analytical chemistry are required. Such a multidisciplinary undertaking is key to achieving a sustainable response to the urgent industrial demand for novel drugs and enzyme varieties.
\end{abstract}

Keywords: blue economy; biopharmaceuticals; bioprospection; host-microbe interactions; gorgonians; polyketides; terpenes

\section{Introduction}

Marine organisms produce a large diversity of unusual, often highly complex, natural products. In fact, the number of new chemical structures reported from marine biomes has been continuously increasing over the past decade (Figure 1a). With over 200 novel chemical structures described every year [1], corals (Cnidaria, Anthozoa) are the second most prolific source of natural products retrieved from marine animals after sponges. Since the first chemical studies on Caribbean gorgonian corals of the genus Pseudopterogorgia in the 1980s [2], corals in the subclass Octocorallia have been considered promising reservoirs of bioactive natural products, including a wealth of novel, unusual terpenoids [3-6]. For example, the diterpenoids caribenols A and B, and elisapterosin B isolated from Pseudopterogorgia elisabethae (now Antillogorgia elisabethae), along with bipinnapterolide B from P. bipinnata, are promising antituberculosis compounds, inhibiting Mycobacterium tuberculosis growth in vitro [3,7]. Pseudopterosin A, a diterpene with anti-inflammatory activity, also obtained 
from P. elisabethae and its dinoflagellate (Symbiodinium sp.) symbiont, has already undergone Phase II human clinical trials where it showed increased reepithelization and accelerated wound-healing [7]. Octocorals lack the physical protection of a massive calcium carbonate skeleton typical for scleractinian corals, and instead rely heavily on chemical defence mechanisms to resist predation and avoid overgrowth and fouling [8]. Their chemical arsenal encompasses not only a variety of terpenoids, particularly sesqui- and diterpenoids, but also steroids, alkaloids, and polyketides $[1,7,9,10]$. Many of these natural products possess potent antibacterial, anti-inflammatory, anticancer, antiviral, antimalarial, and neuroprotective properties $[7,10]$ and are thus of enormous potential for the blue economy sector. Nevertheless, commercial development of coral-derived drugs is scarce, impaired by the fact that large-scale chemical synthesis of complex metabolites is usually unprofitable, and the harvest of large amounts of wild organisms highly unsustainable. Hence, very few compounds complete clinical trials and find their way into the market. Since coral-derived drug reports have traditionally focused on tissue extracts, commonly ignoring the biosynthetic origin of the compounds in question, it is often unclear whether the actual producer is the animal itself or the associated microbial community. Research on marine sponges and bryozoans, for instance, has shown that their bioactive compounds often possess a symbiont origin, revealing marine invertebrates as true hotspots of microbial metabolic versatility [11,12]. We now know that polyketide and terpene synthases are indeed widespread in microorganisms [13-16], and several polyketides and terpenoids have already been identified in marine microbes [17-19]. Current natural-product discovery from marine microorganisms follows an ever-increasing trend, surpassing the numbers of novel invertebrate-derived compounds described per year (Figure 1a,b). In 2006, less than $20 \%$ of all newly discovered marine natural products derived from microbes (including fungi, bacteria, and dinoflagellates), whereas nearly $80 \%$ were registered for invertebrates. In contrast, in 2016 microorganisms were the source of over $50 \%$ of all novel marine natural products, while $40 \%$ still came from invertebrates (Figure 1a). The absolute number of new natural products from marine microorganisms has increased five times over the past decade (Figure $1 \mathrm{~b}$ ), and continued effort to captivate marine microbial life in the laboratory is suggested as a pivotal contribution to this trend. Nearly half $(47 \%)$ of the marine microbes from which novel compounds were retrieved in 2013, for example, had been isolated from host organisms, being marine invertebrates, particularly sponges and octocorals, the most popular hosts (Figure 1c,d). Therefore, new technologies that focus on symbiont-driven production of coral-derived bioactive molecules have the potential to overcome current hindrances in the commercialization of these drugs, contributing to a more sustainable blue economy. Although previous studies have addressed the structural complexity and remarkable biotechnological potential of coral-derived natural products $[5,7,20,21]$, the role of octocoral-associated microbes in the production of these compounds has received little attention. Because of the steep advances in current octocoral microbiology research [22] and of the discovery, in recent years, of highly bioactive natural products from octocoral-associated microbes (see sections below), here we interrogate the microbiomes of these animals as a natural reservoir of novel molecules with inhibitory properties. This review therefore provides a comprehensive inventory of over 80 promising bioactive compounds (Table S1) and various enzymes (Table S2) derived from microbes associated with octocorals. It delineates the major octocoral-associated microbial groups involved in the biosynthesis of natural products, focusing on the astonishing chemical diversity and bioactivity spectrum of these compounds while approaching their medical, pharmaceutical and biotechnological potential. We further employ functional genomics to valorize this potential in an unprecedented fashion, revealing 440 predicted secondary metabolite biosynthetic gene clusters (BGCs) across the genomes of 15 bacterial associates of octocorals, 11 of which corresponding to original genome submissions. We finally debate on future research directions and methodologies leading to minimally invasive and economically reliable retrieval of bioactive secondary metabolites from the highly diverse and chemically complex microbial communities that inhabit octocorals. 
a)

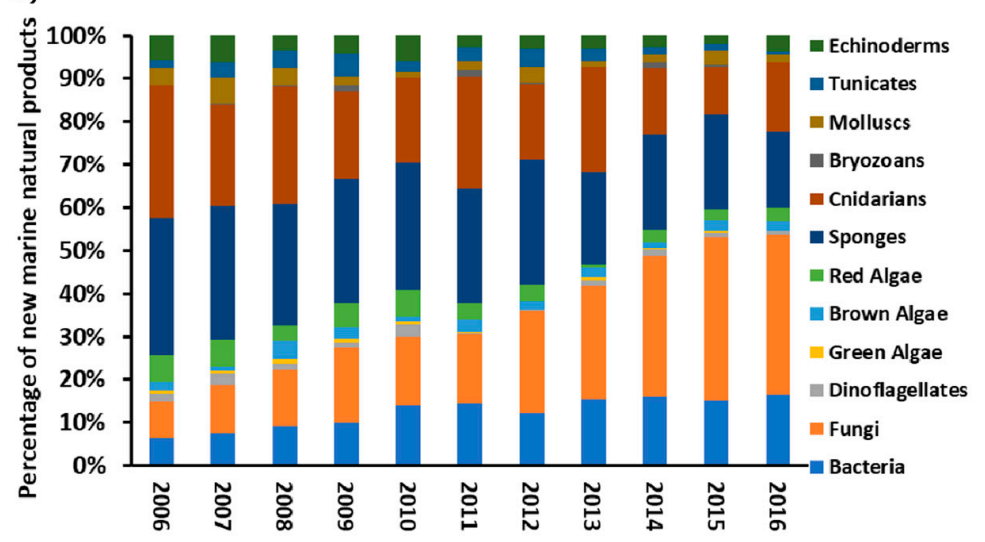

b)

c)



d) Source of Microorganisms

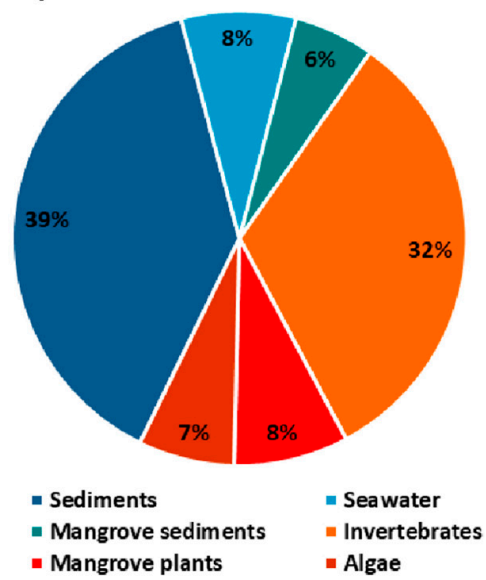

Microorganisms from Invertebrates



$\begin{array}{lll}\text { - Sponges } & \text { Octocorals } & \text { " Echinoderms } \\ \text { - Molluscs } & \text { - Tunicates } & \text { - Crustaceans }\end{array}$

Figure 1. (a) Relative and $(\mathbf{b}, \mathbf{c})$ absolute numbers of new natural products discovered yearly from marine organisms over one decade (2006-2016). Data are based on inventories made by Blunt and colleagues in the 2008-2018 period [1,23-32]. The graphs clearly show an increase of natural products derived from marine microorganisms. Microorganisms (blue) in (b) include bacteria, fungi, and dinoflagellates; invertebrates (brown) include sponges, cnidarians, molluscs, bryozoans, ascidians and echinoderms; marine bacteria (blue) in (c) include cyanobacteria and Mangrove bacteria; marine fungi (green) include Mangrove fungi. (d) Habitat (source) of marine microorganisms (bacteria, fungi, and dinoflagellates) from which novel natural products have been discovered during 2013 (data based on reference [24], sediment and marine invertebrate animals being the dominating habitats). The pie chart on the right-hand side provides a deeper insight into the diversity of the invertebrates that host the producing symbionts, revealing sponges and octocorals as dominating animals. 


\section{Diversity and Function of the Octocoral Microbiome}

Corals are benthic, sessile, suspension-feeding marine invertebrates that live in symbiosis with complex microbial communities, comprised of endosymbiotic dinoflagellates and endolithic algae, fungi, alveolates, bacteria, archaea, and viruses [22,33]. This consortium, consisting of the animal and its associated community of internal and external microorganisms, is commonly referred to as the holobiont [34]. The associated microbes deliver an extra supply of carbon and nitrogen to their host, participate in nutrient cycling and detoxification, UV protection, genetic exchange, and chemical defence of the animal [22,34,35]. Corals are divided into two subclasses, the Hexacorallia, which comprise sea anemones and reef-building hard corals (order Scleractinia) and the Octocorallia, which comprise the orders Helioporacea (commonly referred to as "blue corals"), Pennatulacea (so-called "sea pens"), and Alcyonaceae (including organisms popularly named as "sea fans", "sea whips", and "gorgonians") [36]. Organisms in the latter two orders are also commonly referred to as "soft corals". The term "gorgonian coral", in its turn, is commonly applied to multiple species in the Alcyonaceae order, although the formally accepted taxon Gorgoniidae corresponds to only one of the several families within this order. Octocorals, characterized by the eightfold symmetry of their polyps, are ubiquitous in the world's oceans, and occur from arctic to tropical waters and from shallow reefs to the deep sea. This highly diverse taxon consists of more than 3000 extant species in at least 47 validated families [36]. As true ecosystem engineers, octocorals structure benthic ecosystems where they may contribute to up to $95 \%$ of the total biomass $[37,38]$, determine carbon flux [39], and substantially increase benthic biodiversity [38,40]. Octocoral-microbe interactions have been reviewed recently by van de Water and colleagues [22]. Octocorals in the euphotic zone live in mutualistic association with photosynthetic dinoflagellates of the genus Symbiodinium, which supplies the animal with a substantial amount of energy in form of carbohydrates and participates in nitrogen and phosphorus cycling [22]. Symbiodinium and other microalgal symbionts produce the organic sulphur compound dimethylsulfoniopropionate (DMSP) that can be detected in high concentrations in the tissue of their coral hosts. Coral-associated bacteria of the Roseobacter clade (Alphabroteobacteria) and certain Gammaproteobacteria of the orders Oceanospirillales, Alteromonadales and Vibrionales can breakdown DMSP, playing important roles in sulphur cycling in the coral holobiont [41]. Yet the numerous octocorals that colonize deeper waters lack Symbiodinium symbionts and primarily rely on chemotrophic feeding and interactions with prokaryotic symbiont communities [22,42,43].

Octocoral-bacterial communities are distinct from the surrounding seawater and can be quite diverse in some host species [44] or dominated by a few core microbial taxa in others $[22,45,46]$. Proteobacteria are usually the most represented phylum, followed by Actinobacteria and Bacteroidetes. A core consortium of Oceanospirillales phylotypes related to the genus Endozoicomonas is frequently reported in octocorals and can make up to over $96 \%$ of the bacterial community [22]. Other commonly detected orders are Rhodobacterales, Vibrionales, Alteromonadales, and Cellvibrionales, yet bacterial community composition may vary substantially between host species [22]. For example, the highly valuable, ornamental octocoral Corallium rubrum is highly dominated by Spirochaetales, while Endozoicomonas-like phylotypes are in the minority [47]. Genomic and phenotypic studies suggest that coral/octocoral-associated bacteria may occupy many functional niches within the holobiont, playing roles in nutrient exchange and cycling, amino acid synthesis, and host chemical defence through antibiotic production, thereby actively contributing to shaping the structure of the microbiomes they live in $[22,35]$.

\section{Octocoral-Associated Microbes as Natural-Product Manufacturers}

It has long been suspected that natural-product biosynthesis by microbial symbionts could contribute significantly to the chemical diversity commonly reported for sessile marine invertebrates $[11,15]$. In the past 20 years, the status of marine symbiotic bacteria as true producers of several chemical structures underlying manifold bioactivities was solidified. Thanks to the application of metagenomics-based strategies, much evidence emerged for a prokaryotic genome 
architecture behind the biosynthesis of highly potent compounds often inferred to be produced by so-far uncultivatable symbionts $[11,12,16,48]$. The cultivation-independent discovery of the bryostatin, onnamide, theopederin, psymberin, and ET743 biosynthetic gene clusters, to name a few, and their respective assignment to the genomes of bacterial symbionts (see reference [49] for a review), has considerably furthered our understanding of the ecology and evolution of important marine invertebrate models in natural products research such as marine sponges, bryozoans, tunicates, and scleractinian corals. In contrast, dedicated metagenomics-based assessments of natural-product biosynthesis capacities within octocoral microbiomes have yet to be performed, despite increasing knowledge of their diversity enabled by cultivation-independent approaches [22,44]. Octocoral-associated bacteria presently known to produce bioactive compounds belong to the genera Streptomyces (Actinobacteria), Bacillus (Firmicutes), Vibrio, and Pseudoalteromonas (both Gammaproteobacteria), all obtained in culture. Despite the limited diversity of producers documented to date, the synthesized natural products encompass alkaloids, maleimides, polyketides, and terpenoids with antibacterial, antifungal, antiprotozoal, and cytotoxic activities (Figure 2, Table S1).
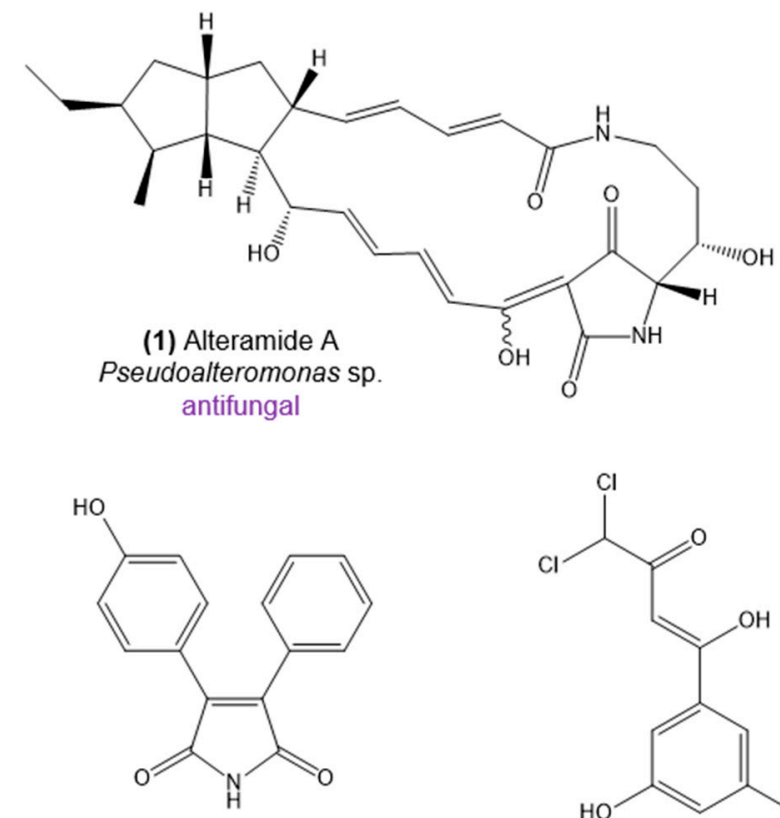

(3) Aquabamycin A Vibrio sp.

antibacterial, antifungal anticancer

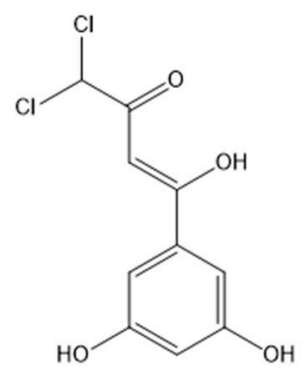

(17) Streptochloritide A Streptomyces $s p$. anticancer

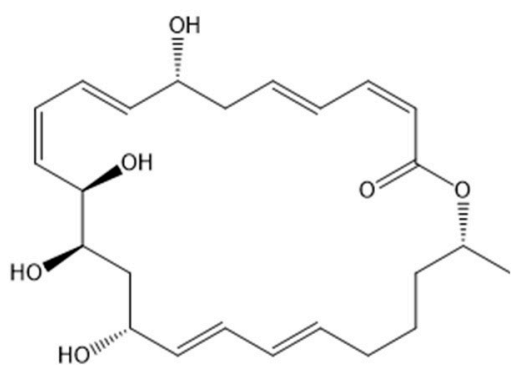

(2) Macrolactin V Bacillus amyloliquefaciens antibacterial

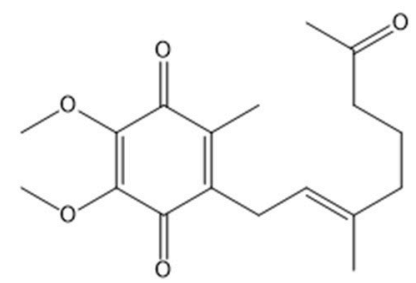

(18) Pseudoalteromone A Pseudoalteromonas $s p$. anticancer

Figure 2. Chemical structures of bioactive natural products from bacteria associated with octocorals. The compounds exhibit antibacterial, antifungal, anticancer, or anti-inflammatory activity. Further information is provided in Table S1.

Knowledge of fungal diversity in octocorals is primarily based on cultivation-dependent strategies and hence restricted to taxa more amenable to cultivation. Nevertheless, those cultured representatives have been a splendid source of bioactive natural products, often with unusual chemical structures (Figures 3 and 4), making octocoral-associated fungi a wealthy target for bioprospecting. Ascomycota is the most frequently cultured phylum from octocorals, with Eurotiomycetes as the most prominent class and Aspergillus and Penicillium as dominating genera [22,50,51]. A variety of Sordariomycetes and Dothidiomycetes fungi are also commonly isolated from octocorals around the world, including the genera Nigrospora, Fusarium, and Cladosporium [22,50,51]. Little is known about the function of these fungi in the coral host, and especially the role of the most frequently isolated genus Aspergillus is controversial. While Aspergillus sydowii has been repeatedly associated 
with fungal disease (aspergillosis) in several host species (e.g., reference [52]), beneficial roles have been suggested for octocoral-associated fungi because of the diverse and highly active natural products they produce, displaying strong antibacterial or antifouling activities (e.g., reference [51]). Currently, Aspergillus spp. are clearly the most prolific producers of natural products among octocoral-associated microbes, as more than 35 bioactive compounds have been described from these species in the last decade. Other bioactive ascomycetes from octocorals are Alternaria, Cochliobolus, Nodulisporium, Penicillium, Pestalotiopsis, Phoma, Trichoderma, and Xylariaceae (Table S1). The diversity of the natural products they synthesize and their activity spectrum is enormous, encompassing anthraquinones, aromatic butenolids, chromones, cyclopeptides, indole alkaloids, lactones, macrolides, orcinols, phenylalanines, polyketides and terpenoids with antiviral, antioxidant, antibacterial, antifungal, antifouling, antimalarial, and anticancer activity (Table S1).<smiles>CCOC(=O)[C@H](Cc1ccccc1)NC(=O)c1ccccc1</smiles>

(4) 4'-methoxyasperphenamat Aspergillus elegans antibacterial<smiles>COC(=O)c1ccc([C@]2(C)CCCC(C)(C)O2)c(O)c1</smiles>

(7) Methyl sydowate Aspergillus sp. antibacterial

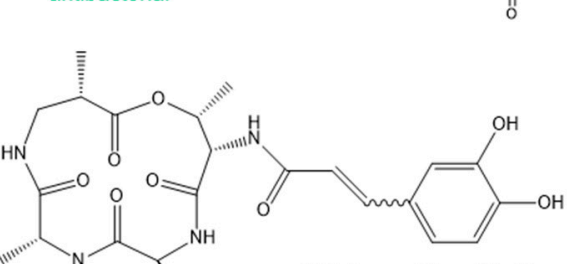

(13) Aspergillipeptide C Aspergillus $s p$ antifouling

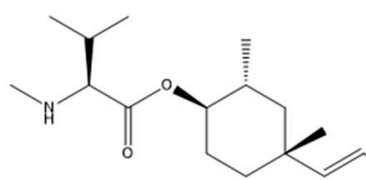

(14) 22-O-(NMe-L-valyl)-21-epiaflaquinolone $\mathrm{B}$ Aspergillus $s p$

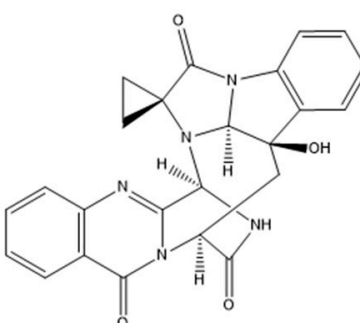

(11) Cottoquinazoline D Aspergillus versicolor antifungal

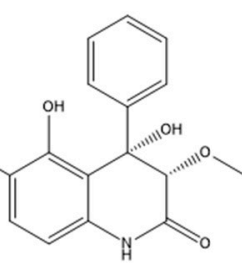<smiles>C/C=C\C(=O)NC(C)C(=O)N[C@@H](C)C(=O)N[C@@H](Cc1ccc(O)cc1)C(=O)N[C@@H](C)C(=O)Nc1ccc(O)cc1C(=O)N(C)C(C)C</smiles>

(5) Asperpeptide A Aspergillus $s p$ antibacterial

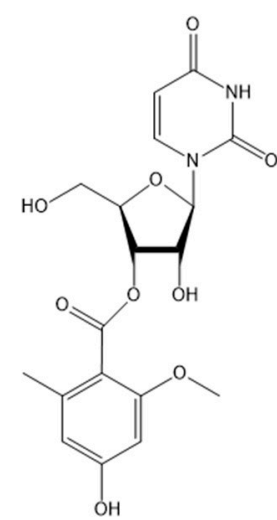

(6) Aroyl uridine derivative Aspergillus versicolor antibacterial
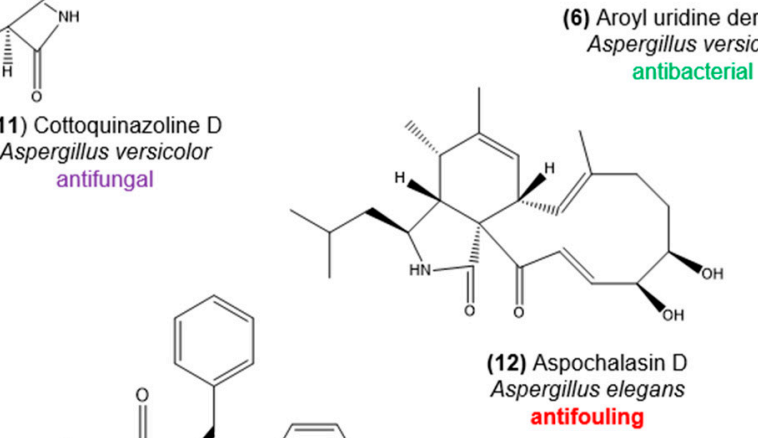



(20) Aspergilone A Aspergillus $s p$. anticancer

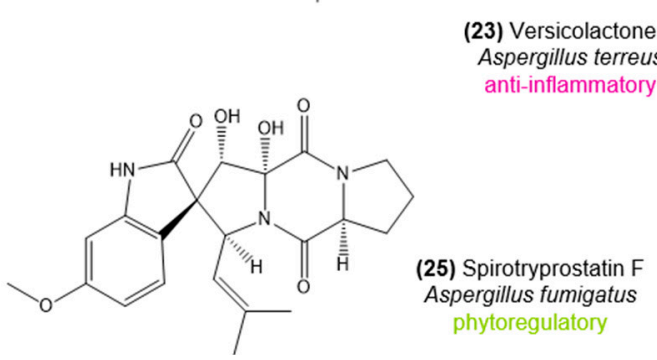

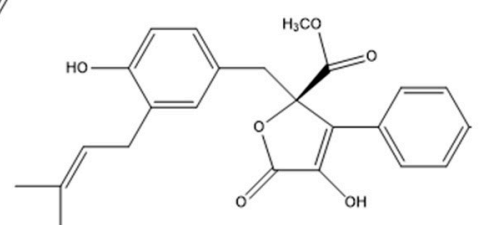

23) Versicolactone $B$ spergillus terreus phytoregulatory

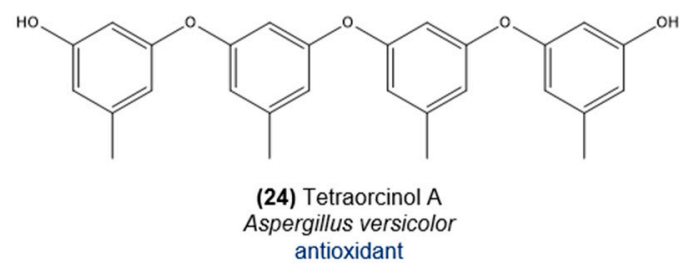

Figure 3. Chemical structures of bioactive natural products from octocoral-associated Aspergillus spp. The activity spectrum of the presented compounds comprises antiviral, antibacterial, antifouling, anticancer, anti-inflammatory, antioxidant, and phytoregulatory effects. Further information is provided in Table S1. 


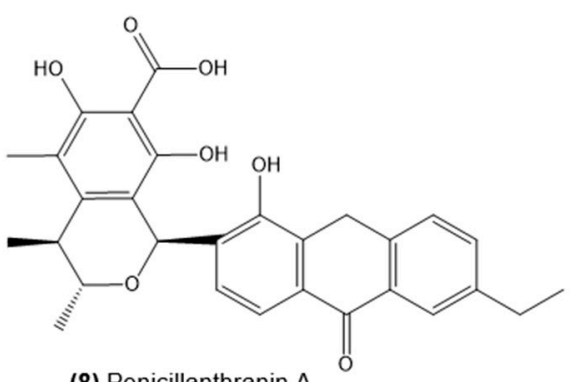

(8) Penicillanthranin A Penicillium citrinum PSU-F51 antibacterial<smiles>COc1cc(O)c2c(c1)C(=O)c1cc(C)c(O)c(-c3c(O)cc4c(c3O)C(=O)c3cc(C)c(C)cc3C4=O)c1C2=O</smiles>
antibacterial
antium commune<smiles>[I-]</smiles><smiles>CC(=O)c1cc(C)c(O)c(Cc2c(O)cc(C)oc2=O)c1O</smiles>

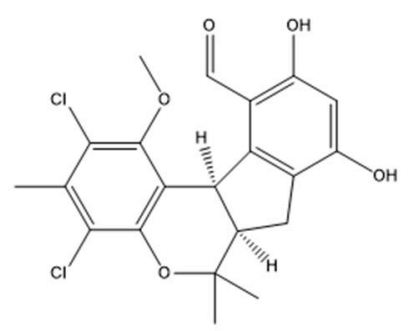

(10) (+)-pestalachloride D Pestalotiopsis sp. antibacterial

Figure 4. Chemical structures of bioactive natural products from fungi associated with octocorals (other than Aspergillus spp.). The compounds exhibit antiviral, antibacterial, anticancer, or antimalarial activity. More information is provided in Table S1.

Below, we provide a comprehensive overview of bioactivities registered for, primarily, bacteria and fungi associated with octocorals. While many of the covered compounds are highlighted in Figures 2-4, a full list of all bioactive compounds documented in this article, along with details on host and microbe identities, is provided in Table S1.

\subsection{Antibacterial and Antifungal Activity}

To cure and prevent infections in humans and animal husbandry, an estimated amount of 100,000 tons of antibiotics is manufactured annually worldwide, resulting in the selection of pathogenic bacteria resistant to multiple drugs [53]. An infamous case is that of methicillin-resistant Staphylococcus aureus (MRSA), which is resistant not only to methicillin but usually also to aminoglycosides, macrolides, tetracycline, chloramphenicol, and lincosamides, acting as a major source of hospital-acquired infections [54,55]. Fungal infections are likewise a serious problem as they cause critical yield losses in the agricultural sector, as well as unpleasant (and eventually severe) diseases, such as candidiasis, in humans. Thus, there is a continued and increasing demand for novel antibiotics and fungicides from the health and agricultural sectors. Fungi and bacteria associated to octocorals have been reported to produce antimicrobial compounds showing activity against Gram-negative and Gram-positive bacteria, filamentous fungi, and yeasts (Table S1).

Pseudoalteromonas sp. strain OT59, isolated from a healthy Leptogorgia alba specimen, produces the polyketide ateramide A (1), a compound that displays light-dependent antifungal activity [56]. In the darkness, both strain OT59 and pure alteramide A inhibit the growth of the ascomycete fungus Penicillium citrinum isolated from the necrotic tissue of a Eunicea sp. specimen. In fact, alteramide A also inhibits several other Penicillium, Aspergillus, Fusarium, and Trichoderma species. Strain OT59 
produces larger quantities of alteramide A in the dark, while light exposure inactivates the compound through photo-induced cyclization. These findings imply that coral-associated bacteria could protect their host from infections during heterotrophic night feeding, when coral polyps are more exposed. However, alteramide A (isolated previously also from a sponge-derived Alteromonas sp. [57]) induces changes in fungal metabolite distribution, promoting higher production of the bacteriostatic antibiotic citrinin and of the mycotoxin citrinadin, which suggests a defensive response of the fungus and highlights the complexity of multipartite interactions.

Bacillus amyloliquefaciens strain SCSIO 00856, isolated from the octocoral Junceella juncea, produces the macrolide macrolactin V (2), which is strongly active against Escherichia coli, Bacillus subtilis, and Staphylococcus aureus, with a minimum inhibitory concentration (MIC) value of $0.1 \mu \mathrm{g} \mathrm{mL}^{-1}$ [58]. Malemeid derivatives aquabamycin A-G (3), active against Micrococcus luteus, Bacillus subtilis, Proteus vulgaris, and Escherichia coli and the fungus Nematospora coryli, are produced by the Vibrio sp. strain WMBA, isolated from the surface of Sinularia polydactyla [59]. In a dual-culture overlay plate assay, two Alphaproteobacteria isolates, strain SC4TGZ4 and Pseudovibrio sp. SC4TGZ3, retrieved from Sinularia sp., showed strong activity against multidrug resistant (MDR) Mycobacterium tuberculosis clinical strains, causative agents of tuberculosis (TB) disease [60]. A similar bioassay was used by Radjasa and Sabdono [61] to assess the antibacterial activity of Sinularia-associated bacterial isolates, whereby actinobacterium strain Athrobacter sp. SFNB.5 was found to inhibit the growth of Vibrio, Staphylococcus, and Tenacibaculum species. Nonribosomal peptide synthase (NRPS) encoding genes were amplified from the genomic DNA of Athrobacter sp. SFNB.5 and suggested to be involved in the observed antibacterial activity. The authors also discuss the potential ecological role of Athrobacter in host defence through the inhibition of biofilm formation by bacterial pathogens.

Aspergillus elegans strain ZJ-2008010, isolated from Sarcophyton sp. (Alcyoniidae), produces the phenylalanine derivatives 4 '-O-methoxyasperphenamate (4) and asperphenamate. These compounds have shown activity against Staphylococcus epidermidis [62], a common member of the human skin microbiome but also a causative agent of chronical infections in patients carrying implanted medical devices, including prosthetic joints, heart valves, and pacemakers [63]. Other agents active against S. epidermidis are the cyclopeptide asperpeptide A (5) and derivatives of the nucleoside aroyl uridine (6) produced by Aspergillus sp. XS-20090B15 (from the host Muricella abnormalis) and Aspergillus versicolor (from the host Dichotella gemmacea), respectively [64,65]. Another Aspergillus sp. strain (ZJ-2008001) from D. gemmacea is the source of phenolic bisabolane-type sesquiterpenoids, including methyl sydowate (7) which is moderately active against $S$. aureus [66]. These compounds were retrieved from marine sponges and the octocorals Pseudopterogorgia rigida, Muricia elongata and Plexaurella nutans [66] as well, indicating that microbial associates may produce such compounds within their hosts in significant amounts. The anthraquinone penicillanthranin A (8), obtained from Penicillium citrinum PSU-F51 associated with the sea fan Annella sp., is active against MRSA strains with an MIC value of $16 \mu \mathrm{g} / \mathrm{mL}$ [67]. Penicillium commune strain 518, isolated from Muricella abnormalis, is the source of several aromatic polyketides, including communol A (9), F, and G, moderately active against E. coli and Enterobacter aerogenes [68]. Pestalotiopsis sp. ZJ-2009-7-6, isolated from Sarcophyton sp., is the producer of the benzophenone derivative ()-pestalachloride D (10), which is active against several Gram-negative bacteria [69]. Aspergillus versicolor strain LCJ-5-4 from the octocoral Cladiella sp., a rich source of cyclopentapeptides and radical-scavenging polyketides [70], also produces the antifungal alkaloid cottoquinazoline D (11) that suppresses the growth of Candida albicans in vitro with an MIC value of $22.6 \mu \mathrm{M}$ [71].

\subsection{Antifouling Activity}

Biofouling is characterized by the superposition of organisms on surfaces, starting with bacterial biofilm formation and advancing with the settlement of micro- and macroalgae and invertebrate larvae [72]. It is a common problem of underwater structures all over the world and an economic threat for shipping, offshore aquaculture, and coastal industries. To prevent this problem, tributyltin (TBT) compounds and other highly ecotoxic chemicals have been used in antifouling paints on hulls of 
ocean-faring vessels. However, due to the enormous environmental threat that TBT compounds present to marine organisms, their application has been completely banned by the International Maritime Organization (IMO) in 2008 [73]. With the ban of TBT-containing antifoulants, research interest in natural products with antifouling activities has been continuously growing. Marine sessile invertebrates, including sponges and corals, and their associated microbes constitute a promising and environmentally friendly source of secondary metabolites that inhibit the settlement and growth of biofouling-causing organisms [72,74].

Octocoral-derived terpenoids are well known for their antifouling properties. For example, the gorgonian coral Junceella juncea is the source of briaran-type diterpenoids juncins R-ZI, juncin ZII, gemmacolide A and B, and junceellolide D, all showing potent activity against barnacle (Balanus amphitrite) larvae settlement with EC50 values from 0.004 to $21.06 \mu \mathrm{g} / \mathrm{mL}$ [75]. There is, in fact, a growing number of reports on antifouling compounds produced by marine microbial symbionts, reviewed recently by Satheesh et al. [72]. Dobretsov and Qian [76] assessed the antifouling effect of epibiotic bacteria isolated from the surface of the octocoral Dendronephthya sp. Two strains, namely, a Vibrio sp. and an unidentified alphaproteobacterium, were found to reduce settlement of the tubeworm Hydroides elegans larvae below 10\% compared to over $80 \%$ larval settlement in controls. Cochliomycin A, produced by the fungus Cochliobolus lunatus isolated from the gorgonian Dichotella gemmaceae, shows strong antifouling activity against larval settlement of the barnacle B. amphitrite with an EC50 value of $1.2 \mu \mathrm{g} / \mathrm{mL}$ (Table S1, [77]). The same gorgonian species is the host of Penicillium sp. producing the polyketide 6,8,50,60-tetrahydroxy-30-methylflavone, which shows significant antifouling activity against $B$. amphitrite larvae settlement with an EC50 value of $6.7 \mu \mathrm{g} / \mathrm{mL}$ (Table S1, [78]). Aspergillus elegans strain ZJ-2008010, source of antibacterial phenylalanine derivatives (see previous section), also produces aspochalasins D (12), I, J, and H, which are cytochalasins that display strong antifouling activity against B. amphitrite larvae [62]. Aspergillipeptide C (13), a cyclic tetrapeptide obtained from Aspergillus sp. SCSGAF 0076 associated with the octocoral Melitodes squamata, strongly inhibits larvae settlement of the bryozoan Bugula neritina with an EC50 value of $11 \mu \mathrm{g} / \mathrm{mL}$ [79]. Similar antifouling activities against B. neritina larvae were reported for indole alkaloids Cyclotryprostatin $B$ and fumiquinazoline $D$, produced by Aspergillus sydowii, associated with the octocoral Verrucella umbraculum (Table S1, [80]). Further antifouling compounds and their source are given in Table S1. Overall, our review uncovered a multitude of compounds from octocoral-associated microbes showing EC50 values much lower than the standard requirement $(E C 50=25 \mu \mathrm{g} / \mathrm{mL})$ established by the U.S. Navy program as an efficacy level for natural antifouling. Testimony to this emerging potential is the fact that some antifouling coatings based on natural products from marine organisms have already found their way into the market, e.g., under the trade names PearlSafe ${ }^{\circledR} \mathrm{TM}$, NetSafe ${ }^{\circledR} \mathrm{TM}$ and SEA-NINETM 211N [72]. SEA-NINE ${ }^{\mathrm{TM}}$ $211 \mathrm{~N}$, a $30 \%$ solution of 4,5-dichloro-2-n-octyl-4-isothiazolin-3-one (DCOIT), is a rapidly biodegradable antifouling agent developed by the Rohm and Haas Company ${ }^{\circledR}$, Philadelphia, PA, USA (now Dow Chemical Company ${ }^{\circledR}$ ) for a new generation of more environmentally acceptable antifouling paints for ships and underwater structures.

\subsection{Antiviral Activity}

Viruses are often highly contagious, causing a variety of severe or even fatal infections in humans and livestock, frequently at epidemic or pandemic scales. Available treatments for viral infections are limited whereas resistance of viruses to the treatments in place is increasing, many times leaving the alleviation of symptoms with analgesics as the only option. Therefore, the search for novel antiviral drugs that allow an effective control of viral infections is paramount. Natural products with antiviral activity retrieved from marine organisms have been reviewed by Cheung et al. [81] and Moghadamtousi et al. [82]. A variety of marine fungi, including the genera Aspergillus, Penicillium, Fusarium, and Cladosporium, produce secondary metabolites with strong antiviral activity, holding promise for further drug development [82]. 
From an ethyl acetate extract prepared from Aspergillus sp. XS-20090B15, isolated from the octocoral Muricella abnormalis, the hydroquinolone 22-O-(NMe-L-valyl)-21-epi-aflaquinolone B (14) was obtained. It showed strong activity (IC50 $=0.042 \mu \mathrm{M})$ against the respiratory syncytial virus (RSV), a common cause of respiratory tract infections in humans that can also lead to the development of bronchiolitis and pneumonia [83]. Alkaloids 9a,14-dihydroxy-6b-p-nitrobenzoylcinnamolide, and 7a,14-dihydroxy-6b-p-nitrobenzoylconfertifolin from Aspergillus sp. strain SCSGAF 0076, isolated from the octocoral Melitodes squamata, and the cyclopeptide asperterrestide A produced by Aspergillus terreus strain SCSGAF0162, isolated from Echinogorgia aurantiaca, inhibit the common human influenza virus A subtypes H1N1 and H3N2 (Table S1, [84,85]). Strain SCSGAF0162 further produces the butyrolactone derivative isobutyrolactone II and the territrem derivative 11a-dehydroxyisoterreulactone A, which possess activity towards the ubiquitous human herpes simplex virus HSV-1 (Table S1, [86]). Anthraquinone alterporriol Q (15) and the hydroanthraquinone tetrahydroaltersolanol C, obtained from a standing culture broth of Alternaria sp. ZJ-2008003, retrieved from Sarcophyton sp., showed antiviral activity against the porcine reproductive and respiratory syndrome virus (PRRSV), the most impacting infectious disease of pigs worldwide (Table S1 [87]). The polyketide-cyclopeptide (PKS-NRPS) metabolites (-) and (+)-pestaloxazine A (16) produced by Pestalotiopsis sp., also isolated from the octocoral Sarcophyton sp., showed antiviral activity against human Enterovirus 71 (EV71), the causative agent of hand, foot, and mouth disease (HFMD) that can lead to severe neurological complications in young children and infants [88].

\subsection{Anticancer Activity}

Cancer, characterized by the uncontrolled growth and spread of abnormal cells, is the second leading cause of death globally, accounting for 8.8 million fatal cases in 2015 (World Health Organization, http://www.who.int/cancer/en/). Since 1990, there has been a continuous increase in the number of anticancer compounds derived from marine sources that have progressed into preclinical and human clinical trials. Five marine invertebrate-derived compounds (at least) have been approved by the U.S. Food and Drug Administration (FDA) or the European Medicines Agency (EMA) as anticancer drugs [89]. Natural products from octocorals have a wide activity spectrum against several human cancer cell lines, including colon and lung adenocarcinoma, breast, cervix, hepatocellular and gingival carcinoma, prostate, gastric, and central nervous system cancer, and lymphocytic leukemia [90-95]. Since 2010, multiple bacterial and fungal associates from various octocoral species have been identified as producers of anticancer compounds with an equally ample activity spectrum (Table S1).

For example, the soft-coral associated Streptomyces sp. OUCMDZ-1703 produces the chlorinated polyketides streptochloritide A and B (17) that possess cytotoxicity against breast cancer (MCF-7) cells (IC50 values of 9.9 and $20.2 \mu \mathrm{M}$, respectively) [96]. The ubiquinone-monoterpenoid derivative pseudoalteromone A (18), produced by Pseudoalteromonas sp. CGH2XX associated with Lobophytum crissum, is cytotoxic to human acute lymphoblastic leukemia (MOLT-4) cells, and shows anti-inflammatory activity by inhibiting the release of elastase by human neutrophils [97]. Vibrio sp. strain WMBA, obtained from the surface of Sinularia polydactyla, is the producer of several maleimide derivatives and aqabamycins (e.g., aqabamycin A (3)) that show, besides the antibacterial and antifungal activities mentioned above, cytotoxic effects against several cancer cell lines [59]. The basidiomycete fungus Chondrostereum sp., isolated from Sarcophyton tortuosum, is a rich source of hirsutane-framework sesquiterpenoids. However, its metabolic profile varies substantially depending on the composition of the culture medium [98]. In potato dextrose broth (PDB), the sesquiterpenoids chondrosterin A-E can be isolated, with chondrosterin A (19) showing significant cytotoxic activity against human lung carcinoma (A549), nasopharyngeal carcinoma (CNE-2), and human colon (LoVo) cancer lines, with IC50 values of $2.45,4.95$, and $5.47 \mu \mathrm{M}$, respectively [99]. In the same medium, the fungal associate also produces incarnal, which is cytotoxic towards eight different cancer cell lines [100]. When grown on glucose peptone yeast extract (GPY) medium prepared in seawater, 
hirsutanol A, E and F can be obtained. Hirsutanol A shows potent cytotoxicity against 15 different cancer cell lines, including human colon, lung, hepatic, nasopharyngeal, breast, and cervical cancer lines with IC50 values ranging from 0.58 to $8.27 \mu \mathrm{g} / \mathrm{mL}$ [101]. In general, IC50 values below $50 \mu \mathrm{g} / \mathrm{mL}$ are considered as active. Finally, when the fungus is cultured in liquid medium containing glycerol as carbon source, the sesquiterpenoid chondrosterin J can be harvested, which shows potent cytotoxic activities against nasopharyngeal carcinoma CNE-1 and CNE-2 cell lines, with IC50 values of 1.32 and $0.56 \mu \mathrm{M}$, respectively (Table S1). The cytotoxic effect of chondrosterin J is even stronger than those of chondrosterin A, hirsutanol A (CNE-1: $10.08 \mu \mathrm{M}$; CNE-2: $12.72 \mu \mathrm{M})$, and incarnal (CNE-1: $34.13 \mu \mathrm{M}$; CNE-2: $24.87 \mu \mathrm{M}$ ) [98]. This exemplifies that medium composition (and culture conditions) greatly impact the diversity (and quantity) of fungal secondary metabolites, highlighting the importance of the optimization of growth conditions for industrial upscaling. The ascomycete fungus Alternaria sp. ZJ-2008003, obtained from Sarcophyton sp., produces the anthraquinone alterporriol P, which is cytotoxic to human prostate adenocarcinoma (PC-3) and colon carcinoma (HTC-116) cells with IC50 values of 6.4 and $8.6 \mu \mathrm{M}$, respectively [87]. The ethyl acetate extract of an Aspergillus sp. strain isolated from Dichotella gemmacea exhibited significant cytotoxicity against a human lung carcinoma (A-549) cell line. Further investigation into this bioactive extract led to the identification of a new azaphilone derivative, aspergilone A (20), which exhibits cytotoxicity towards HL-60 human promyelocytic leukemia, MCF-7 human breast adenocarcinoma and A-549 human lung carcinoma cell lines [102]. Moreover, the chromones oxalicumone A (21) and B produced by Penicillium oxalicum isolated from Muricella flexuosa exhibit cytotoxicity against skin (A375) and colon (SW-620) cancer cells, whereby oxalicumone $\mathrm{A}$ is more potent [103].

\subsection{Antimalarial, Anti-Inflammatory, Antineurodegenerative and Other Activities}

Some protozoans, when transmitted to humans (generally via an animal vector), cause serious infectious diseases, such as malaria, sleeping sickness, Chagas' disease, or toxoplasmosis, which pose a significant threat to global health, particularly in tropical and subtropical regions. Malaria develops upon being stung by a mosquito that carries a Plasmodium-type (protozoan) parasite (commonly Plasmodium falciparum) and is still a leading cause of morbidity and mortality in Africa, where 90\% of all cases occur (WHO, July 2018, http:/ / www.who.int/malaria/en/). Natural products play an important role in the eradication of malaria, and marine organisms are an excellent source of novel antiprotozoal compounds. However, reports on antiplasmodial or antiprotozoal activities of compounds derived from octocoral-associated microorganisms are still scarce. Yet one notable example is the tetronic acid nodulisporacid A (22), produced by the octocoral-associated ascomycete Nodulisporium sp. CRIF1, which exhibits promising activity against chloroquine-resistant $P$. falciparum strain 94, with IC50 values of 1-10 $\mu \mathrm{M}$ (Table S1 [104]).

Inflammation processes are correlated with the activation of the immune system in response to microbial infections, irritation or injury on tissues or organs. Pseudopterosins are diterpene glycosides retrieved from Pseudopterogorgia elisabethae (now Antillogorgia elisabethae) and rank among the first octocoral-derived compounds with described anti-inflammatory activity [2]. Pseudopterosin A has already undergone Phase II human clinical trials led by the Regents of the University of California [89], where it showed increased reepithelization and accelerated wound-healing processes [105]. In 2003, Mydlarz and colleagues demonstrated that the dinoflagellate symbiont Symbiodinium sp. is capable of synthesizing the Pseudopterosins A to D (Table S1) in physiologically significant levels, both from inorganic carbon and from the precursor geranylgeranyl-diphosphate [106], pointing out a symbiont origin of these anti-inflammatories. Proinflammatory enzymes, including the inducible nitric oxide synthase (iNOS), are key in the development of inflammatory diseases. Macrophages are among the leukocyte populations that can escalate the inflammation process and show enhanced expression of NOS enzymes. Therefore, in vitro anti-inflammatory activity is frequently assessed by the inhibition of the expression or production of iNOS proteins and by the inhibition of NO generation in macrophage cells [107]. An Aspergillus terreus strain isolated from Sarcophyton subviride is the producer of 
versicolactone B (23), a lactone that shows anti-inflammatory effects by inhibiting NO production in mouse macrophages ([108], see Table S1 for details). More lactones, including a variety of territrem derivatives, can be obtained from Aspergillus terreus strain SCSGAF0162, isolated from Echinogorgia aurantiaca. Some of these tremorgenic mycotoxins, including territrem D and E, show strong acetylcholinesterase (AChE) inhibitory activity with IC50 values of 4.2 and $4.5 \mathrm{nM}$, respectively. AChE inhibitors are currently among the most effective treatment targets for the design of drug candidates against Alzheimer's disease, a neurodegenerative disorder that is the most common cause of dementia among the elderly [86].

Further interesting activities described for compounds from octocoral-associated microorganisms include antioxidant, insecticidal, and phytoregulatory effects. For example, Aspergillus versicolor LCJ-5-4, retrieved from the finger leather coral Cladiella sp., is the producer of tetraorcinol A (24), an orcinol with antioxidant activity, which functions as a scavenger against the 2,2-diphenyl-1-picrylhydrazyl (DPPH) radical [70]. Chrodrimanin B, a meroterpenoid composed of a sesquiterpenoid and a polyketide moiety, has been described for an Aspergillus sp. associated with the octocoral Dichotella gemmacea [109]. The compound exhibits insecticidal activity by blocking insect GABA-gated chloride channels [110]. The cyclopeptide-alkaloid spirotryprostatin F (25) from Aspergillus fumigatus, retrieved from Sinularia sp., shows phytoregulatory activity in low and ultralow doses, stimulating the growth of sprout roots of soy, corn, and buckwheat [111].

\section{Genomic Insights into Natural Product Biosynthesis by Bacterial Symbionts of Octocorals}

Most culture collections of octocoral-associated bacteria published to date are rather small-sized, representing a reduced taxonomic diversity (consisting mostly of Vibrio spp.) usually retrieved from diseased coral tissue [112-114]. This and the general difficulty to captivate marine prokaryotes in the laboratory likely explain why reports on natural products from octocoral symbionts are still relatively limited. Recently, we developed an alternative strategy that enabled the cultivation of many dominant bacterial symbionts from the gorgonian coral Eunicella labiata [44], a prolific source of anticancer diterpenoids [5,115]. The isolated symbionts encompassed 13 classified and two unclassified bacterial genera within 7 bacterial families, including a variety of Alphaproteobacteria species. Genome sequencing of three such isolates, Aquimarina sp. strain EL33 [116], Sphingorhabdus sp. strain EL138 [117], and Labrenzia sp. strain EL143 [118], suggested versatile secondary metabolisms. Using antiSMASH v.3 [119], we have now mined 11 genomes representing different bacterial genera isolated from E. labiata by Keller-Costa et al. [44], in addition to four genomes from Vibrio strains associated with healthy and diseased Eunicella verrucosa specimens $[120,121]$, for the presence of secondary metabolite biosynthetic genes clusters (BGCs). A total of 440 BGCs were found across the 15 genomes. These encompassed, primarily, terpene $(N=7)$, polyketide [PKS] $(N=14$, i.e., $5 \times$ T1-PKS; $2 \times$ transAT-PKS; $3 \times$ T3-PKS; $4 \times$ other PKS), thiopeptide $(N=2)$, nonribosomal peptide [NRPS] $(N=4)$, bacteriocin $(N=15)$, arylpolyene $(N=7)$, and homoserine lactone [HSL] $(N=18)$ BGCs, besides many putative clusters (Figure 5). Terpene BGCs were found in the genomes of Aquimarina sp. EL33 (Bacteroidetes) and of the Alphaproteobacteria strains Labrenzia sp. EL143, Sphingorhabdus sp. EL138, Kiloniella sp. EL199, Roseovarius sp. EL26, and Rhodobacteraceae strain EL53 (closest genus Phaeobacter). Most of these terpenoid clusters do not present high homology to known clusters, highlighting the potential for the discovery of new natural products and biosynthetic pathways within these bacteria. Only the terpenoid gene cluster of Sphingorhabdus strain EL138 was found to share high homology with a known BGC, presenting 75\% similarity with the gene cluster encoding the carotenoid astaxanthin [117]. This terpenoid is commercialized as a food dye, antioxidant, and nutritional supplement to prevent diabetes, cardiovascular diseases, neurodegenerative disorders, or cancer, and to stimulate immunization [122]. 
Table 1. Protein families (PFAM) and/or cluster of orthologous groups (COGs)-based annotation of terpene, polyketide, and antibiotic encoding genes present on the genomes of 15 octocoral (Eunicella labiata and E. verrucosa) associated bacteria (Alphaproteobacteria $(N=9)$, Gammaproteobacteria $(N=5)$, and Bacteroidetes $(N=1)$ ).

\begin{tabular}{|c|c|c|c|c|c|c|c|c|c|c|c|c|c|c|c|c|c|c|}
\hline \multirow[b]{2}{*}{ Category } & \multirow[b]{2}{*}{ Accession } & \multirow[b]{2}{*}{ Name } & \multirow[b]{2}{*}{ Description } & \multicolumn{15}{|c|}{ Number of Open Reading Frames Detected per Gorgonian-Associated Bacterial Genome } \\
\hline & & & & 产 & 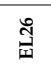 & ज্] & 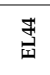 & 菑 & $\begin{array}{l}\text { స్ } \\
\text { స్ }\end{array}$ & 丞 & 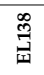 & $\stackrel{2}{\vec{I}}$ & 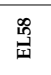 & $\stackrel{\mathbb{3}}{\mathbb{H}}$ & $\frac{8}{8}$ & 畐 & 胥 & \\
\hline \multirow{2}{*}{$\begin{array}{c}\text { Monoterpene synthesis and } \\
\text { metabolism }\end{array}$} & PF03088.9 & Str_synth & Strictosidine synthase & 1 & 0 & 0 & 0 & 2 & 0 & 0 & 2 & 0 & 0 & 3 & 0 & 0 & 0 & \\
\hline & PF07858.5 & LEH & Limonene-1,2-epoxide hydrolase catalytic domain & 0 & 0 & 0 & 0 & 0 & 0 & 0 & 3 & 0 & 0 & 1 & 0 & 0 & 0 & \\
\hline \multirow{4}{*}{$\begin{array}{l}\text { Tri- and tetraterpene } \\
\text { synthesis }\end{array}$} & PF00494.12/COG1562 & SQS_PSY/ERG9 & Squalene/phytoene synthase & 1 & 1 & 1 & 1 & 1 & 1 & 1 & 2 & 1 & 0 & 1 & 0 & 0 & 0 & \\
\hline & $\begin{array}{l}\text { COG1233 } \\
\text { PFo14913 }\end{array}$ & $\underset{S E}{\operatorname{COG} 1233}$ & $\begin{array}{l}\text { Phytoene dehydrogenase and related proteins } \\
\text { Suarlene epoxidase }\end{array}$ & $\begin{array}{l}0 \\
0\end{array}$ & $0_{0}^{0}$ & ${ }_{0}^{1}$ & ${ }_{0}^{2}$ & 0 & 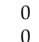 & $\begin{array}{l}1 \\
1\end{array}$ & $\begin{array}{l}2 \\
0\end{array}$ & $\begin{array}{l}0 \\
0\end{array}$ & $\begin{array}{l}0 \\
0\end{array}$ & $\begin{array}{l}3 \\
0\end{array}$ & $\begin{array}{l}0 \\
1\end{array}$ & $\begin{array}{l}0 \\
1\end{array}$ & $\begin{array}{l}0 \\
1\end{array}$ & \\
\hline & $\begin{array}{l}\text { PFF8491.3. } \\
\text { P005834.5 }\end{array}$ & $\begin{array}{c}\text { SE } \\
\text { Lycopene cycl }\end{array}$ & $\begin{array}{l}\text { Squalene epoxidase } \\
\text { Ixopene }\end{array}$ & 0 & 0 & 0 & 0 & 1 & 0 & 1 & 0 & 0 & 0 & 0 & 1 & 1 & 1 & 1 \\
\hline & $\begin{array}{l}\text { PF07143.4 } \\
\end{array}$ & & $\begin{array}{l}\text { Lycopene cyclase protein } \\
\text { Hydroxyneurosporene synthase }\end{array}$ & 1 & 0 & 1 & 0 & 1 & $\begin{array}{l}0 \\
0\end{array}$ & $\begin{array}{l}0 \\
0\end{array}$ & 0 & $\begin{array}{l}0 \\
0\end{array}$ & $\begin{array}{l}3 \\
1\end{array}$ & 0 & 2 & $\begin{array}{l}0 \\
2\end{array}$ & $\begin{array}{l}0 \\
2\end{array}$ & 2 \\
\hline \multirow{6}{*}{ Polyketide synthases } & PF08392.5 & FAE1_CUT1_RppA & FAE1/Type III polyketide synthase-like protein & 0 & 1 & 0 & 0 & 1 & 1 & 0 & 1 & 1 & 0 & 0 & 0 & 0 & 0 & 0 \\
\hline & PF00195.12 & Chal_sti_synt_N & $\begin{array}{l}\text { Chalcone and stilbene synthases, } \\
\text { N-terminal domain }\end{array}$ & 0 & 0 & 1 & 1 & 1 & 0 & 1 & 1 & 0 & 0 & 2 & 0 & 0 & 0 & 0 \\
\hline & PF02797.8 & Chal_sti_synt_C & $\begin{array}{l}\text { Chalcone and stilbene synthases, } \\
\text { C-terminal domain }\end{array}$ & 0 & 0 & 0 & 0 & 0 & 0 & 1 & 1 & 0 & 0 & 0 & 0 & 0 & 0 & 0 \\
\hline & COG2761 & FrnE & $\begin{array}{l}\text { Predicted dithiol-disulfide isomerase involved in } \\
\text { polyketide biosynthesis }\end{array}$ & 2 & 1 & 1 & 1 & 2 & 1 & 1 & 2 & 2 & 1 & 1 & 1 & 2 & 2 & 1 \\
\hline & COG3321 & COG3321 & Polyketide synthase modules and related proteins & 1 & 0 & 1 & 1 & 1 & 1 & 0 & 11 & 0 & 0 & 11 & 2 & 1 & 1 & 1 \\
\hline & COG5285 & COG5285 & $\begin{array}{l}\text { Protein involved in biosynthesis of mitomycin } \\
\text { antibiotics / polyketide fumonisin }\end{array}$ & 2 & 1 & 2 & 1 & 1 & 1 & 0 & 2 & 1 & 0 & 0 & 0 & 0 & 0 & 0 \\
\hline \multirow{3}{*}{ Polyketide cyclases } & PF03364.13 & Polyketide_cyc & Polyketide cyclase/dehydrase and lipid transport & & 1 & 1 & 1 & 1 & 1 & 1 & 0 & 1 & 1 & 0 & 1 & 1 & 1 & 1 \\
\hline & PF10604.2 & Polyketide_ & Polyketide cyclase/dehydrase a & 5 & 3 & 2 & 4 & 1 & 4 & 8 & 3 & 0 & 0 & 5 & 0 & 0 & 0 & \\
\hline & PF07366.5 & Snoal & SnoaL-like polyketide cyclase & 26 & 8 & 8 & 11 & 7 & 5 & 20 & 9 & 1 & 0 & 16 & 15 & 6 & 15 & 2 \\
\hline Nonribosomal peptides & PF08415.3 & NRPS & Nonribosomal peptide synthase & 2 & 0 & 0 & 0 & 0 & 0 & 0 & 0 & 0 & 0 & 0 & 0 & 0 & 0 & 0 \\
\hline \multirow{2}{*}{ Amino-glycoside antibiotics } & PF02522.7 & Antibiotic_NAT & Amin & 0 & 0 & 0 & 0 & 0 & 0 & 0 & 0 & 0 & 0 & 1 & 1 & 0 & 0 & 0 \\
\hline & PF03992.9 & $\mathrm{ABM}$ & Antibiotic biosynthesis monooxygenase & 11 & 9 & 5 & 2 & 2 & 4 & 11 & 9 & 6 & 2 & 5 & 6 & 6 & 6 & 6 \\
\hline \multirow{2}{*}{$\begin{array}{c}\text { Polycyclic peptide } \\
\text { antibiotics }\end{array}$} & PF04/37.6 & & & 0 & 0 & 0 & 0 & 0 & 0 & 0 & 0 & 0 & 0 & 2 & 0 & 0 & 0 & 0 \\
\hline & PF04738.6 & Lant_dehyd_C & Lantibiotic dehydratase, C-terminus & 0 & 0 & 0 & 0 & 0 & 0 & 0 & 0 & 0 & 0 & 1 & 0 & 0 & 0 & 0 \\
\hline
\end{tabular}

For each (amino acid-translated) bacterial genome, PFAMs and COGs were predicted using the WebMGA platform (http://weizhong-lab.ucsd.edu/metagenomic-analysis/) and COG and PFAM entries relevant for terpene, polyketide, and/or antibiotic biosynthesis are shown. All "EL" strains have been isolated from the gorgonian coral Eunicella labiata as described in reference [44]. All "Ev" strains have been obtained from the gorgonian coral Eunicella verrucosa as described in reference [121]. "Evh" strains derive from healthy, while "Evd" strains derive from necrotic E. verrucosa tissue. Bacterial strain names and corresponding genome sequence accession numbers are as follows: Ruegeria sp. EL01 (OMPS01000001-OMPS01000049); Roseovarius sp. EL26 (OUMZ01000001-OUMZ01000007); Pseudophaeobacter sp. EL27 (OMPQ01000001-OMPQ01000016); Sulfitobacter sp. EL44 (OMPT01000001-OMPT01000014); Rhodobacteraceae strain EL53 (OMPR01000001-OMPR01000019); Rhodobacteraceae strain EL129 (ONZJ01000001-ONZJ01000003); Labrenzia sp. EL143 (OGUZ01000001-OGUZ01000034 [118]; Sphingorhabdus sp. EL138 (OGVD01000001-OGVD01000004 [117]); Kiloniella sp. EL199 (OMPU01000001-OMPU01000019); Aliivibrio sp. EL58 (OMPC01000001-OMPC01000012); Aquimarina sp. EL33 (FLRG01000001-FLRG01000020 [116]; Vibrio sp. strain Evd3 (ORXW01000001-ORXW01000013); Vibrio sp. Evd11 (OSDX01000001-OSDX01000117); Vibrio sp. Evh12 (FAUO01000001-FAUO01000017 [120]); Vibrio sp. Evh13 (OSDW01000001-OSDW01000043). 


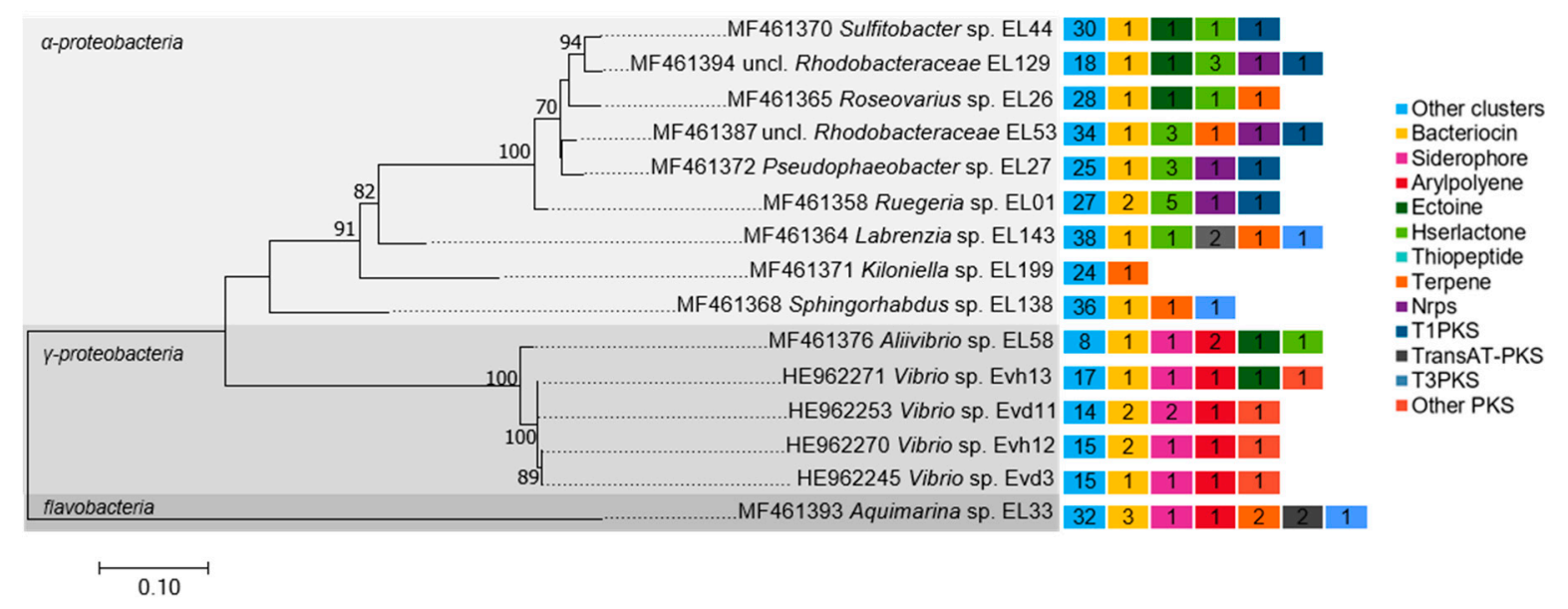

Figure 5. Secondary metabolite biosynthetic gene clusters (BGCs) from bacteria associated with octocorals. Right: the type and number of BGCs present on the genome sequences of 15 bacteria isolated from the gorgonian corals Eunicella labiata (EL) and E. verrucosa (Evh-healthy; Evd-diseased) are presented. Biosynthetic clusters were identified using the bacterial version of antiSMASH 3.0 [119]. Genome sequences are available under the accession numbers presented in the legend to Table 1. Left: 16S rRNA gene-based phylogenetic relationship of the 15 symbionts. The $16 \mathrm{~S}$ rRNA gene tree was constructed in MEGA7 using the Maximum Likelihood method and General Time Reversible model with a discrete gamma distribution and invariable sites $(\mathrm{GTR}+\mathrm{G}+\mathrm{I})$. Sequences were aligned using CLUSTALW algorithm prior to bootstrapped tests (100 repetitions) of phylogeny. Corresponding $16 \mathrm{~S}$ rRNA gene-sequence accession numbers are given before each strain name.

Besides BGCs prospection with antiSMASH, protein family (PFAM)-based analysis detected strictosidine synthase (EC 4.3.3.2) involved in monoterpenoid indole alkaloid biosynthesis on the genomes of several alphaproteobacterial strains (Ruegeria sp. EL01, Rhodobacteraceae strain EL53 and Sphingorhabdus sp. EL138) as well as on the Aquimarina sp. EL33 genome (Table 1). Additionally, Sphingorhabdus sp. EL138 and Aquimarina sp. EL33 possessed a limonene-1,2-epoxide hydrolase (EC 3.3.2.8) involved in monoterpene metabolism and degradation (Table 1). All 15 Eunicella-derived bacterial genomes possessed one or more genes for tri- and/or tetraterpenoid synthesis according to PFAM annotations. At least one squalene or phytoene synthase (EC 2.5.1.21/EC 2.5.1.32) gene involved in steroid or carotenoid synthesis was present on all the nine Alphaproteobacteria genomes and on the Aquimarina genome. Squalene epoxidase (PF08491.3) encoding genes for sterol biosynthesis were present on the genomes of Labrenzia sp. EL143, Rhodobacteraceae strain EL53, and all four Vibrio strains, while genes encoding for lycopene cyclases (PF05834.5) and hydroxyneurosporene synthase (PF07143.4) for carotenoid synthesis were found on the genomes of 10 of the 15 Eunicella associates (Table 1). This points to a widespread, yet uncharted capacity of octocoral bacterial associates to synthesize and metabolize terpenes, potentially contributing to the vast diversity of bioactive terpenoids characteristic of these animals. Furthermore, gene clusters involved in the biosynthesis of diverse polyketide synthases (PKS) and cyclases were noticeably present across all the inspected genomes (Table 1). AntiSMASH screening identified a polyketide BGC in seven out of nine Alphaproteobacteria associates (Figure 5). While the Labrenzia sp. EL143 genome contained a thiopeptide-trans-AT-PKS-NRPS hybrid and a T3-PKS cluster, all other strains in the Rhodobacteraceae family typically possessed a T1-PKS cluster. Sphingorhabdus sp. EL138 also possessed a putative T3-PKS gene cluster, whereas four PKS clusters were present on the Aquimarina genome, namely two T3-PKS and two trans-AT-PKS clusters. Thus, bacterial symbionts of octocorals are well-equipped for the synthesis of a wealth of polyketides, likely with pharmacologically relevant activities. Moreover, all the 15 genomes contained an ABM domain (PF03992.9) which is typically found in monooxygenases involved in the biosynthesis of several antibiotics (Table 1). Aquimarina sp. EL33 also harboured the lodAB operon responsible for the biosynthesis of marinocine [116], a lysin oxidase, 
antimicrobial protein that provokes cell death by generating hydrogen peroxide [123]. Our outcomes strengthen the notion of highly diversified secondary metabolisms among bacterial associates of octocorals, yet functional and comparative genomics approaches have seldom been applied to the study of octocoral-associated microorganisms. Type 2-PKS genes have been amplified from several Actinomycetes strains of the genera Micromonospora (6) and Streptomyces (4) isolated from the octocoral Scleronephthya sp. [124], and the authors also identified an analogue of the T2-PKS derived natural product jadomycin B, known for its cytotoxic and antibacterial activities [125], in the fermentation broth of Micromonospora strain A5-1.

\section{Genomic Insights into Biocatalysts}

Industrial biocatalysis is a growing field with a wide range of applications, such as the biotreatment of waste and toxic chemicals, the improvement of food quality and its storage, the processing of several materials, such as paper and leather, and additives for detergents. The use of enzymes as catalysts is usually much cleaner and less hazardous than the use of chemical ones. Enzymes from marine organisms are frequently characterized by unique, habitat-related properties such as salt tolerance, hyper thermostability, barophilicity, cold adaptivity, or high pH tolerance [126], offering new types of biotechnological applications. While mining the 15 abovementioned bacterial genomes for the presence of BGCs, we noticed a wealth of genes encoding for the biosynthesis of several important biocatalysts, from chitinases to cellulases, amylases and a variety of proteases. This information has been compiled and discussed in Supplementary File S1 and Table S2.

\section{Optimization of Bioactive Compound Production to Meet Industrial Demands}

As noticed above, the number of natural products discovered from marine microorganisms has sharply increased over the past decade, with octocorals being prosperous hosts of bacterial and fungal producers of secondary metabolites. This reservoir of bioactive microbes offers exciting alternatives to the often unprofitable and complicated chemical synthesis of natural products, and the unsustainable harvest of slow-growing and declining wild coral populations. Instead, microbial-derived bioactive compounds can be obtained from only tiny amounts $(0.1-1 \mathrm{~g})$ of coral material, being such quantities sufficient to establish culture collections of hundreds to thousands of bacterial or fungal associates. Efforts should therefore be directed towards the development and optimization of methodologies that lead to minimally invasive and economically reliable retrieval of bioactive secondary metabolites from the diverse and chemically complex microbial communities inhabiting octocorals. However, multiple challenges are to be met and overcome on the long path towards clinical trials and drug approval. In fact, the number of biotechnological processes described for large-scale production of marine, microbial-derived bioactive compounds is far from the sum of the newly discovered natural products [127]. Large pharmaceutical enterprises tend to be risk-aversive in their research and development programs and take up product-commercialization processes only at advanced stages. It is, thus, often left to research institutions and small spin-off and start-up companies to take on the early, risky steps of drug development, including production optimization, safety assessment, and first clinical trials $[128,129]$. To improve microbial-driven production processes, the following areas (summarized in Figure 6) need investment from research institutions and companies alike. At first, innovative cultivation strategies that expand the taxonomic and metabolic breath of cultivatable microbial communities should be sought. This would undoubtedly aid the continuous supply of novel bioactive compounds. The taxonomic variety of octocoral associated microbes present in culture collections is still quite small compared to the expected number of phylotypes as assessed by amplicon-based metagenomics surveys [22]. Because studies addressing the cultivatable fraction of the octocoral microbiome in a comprehensive fashion are scarce, the number of complete genome sequences from octocoral symbionts in public databases are prohibitively low in comparison with the broad range of symbiotic bacteria already well-characterized from other systems such as the marine sponge, rhizosphere, and human microbiomes. We have recently shown 
that the cultivatable fraction of octocoral-associated bacteria can be successfully expanded with relatively simple measures, such as reduced nutrient content in the culture medium, lower incubation temperatures, and prolonged incubation time [44]. Further success is expected from new medium formulations that contain specific nutrients envisaged to correspond to the dietary needs of symbiotic microorganisms. Here, functional metagenomics studies of octocoral microbiomes can help to predict the nutritional demands of symbionts, as valuable insights into abundant catabolic enzymes involved in nutrient metabolism can be gathered from shotgun sequencing projects.

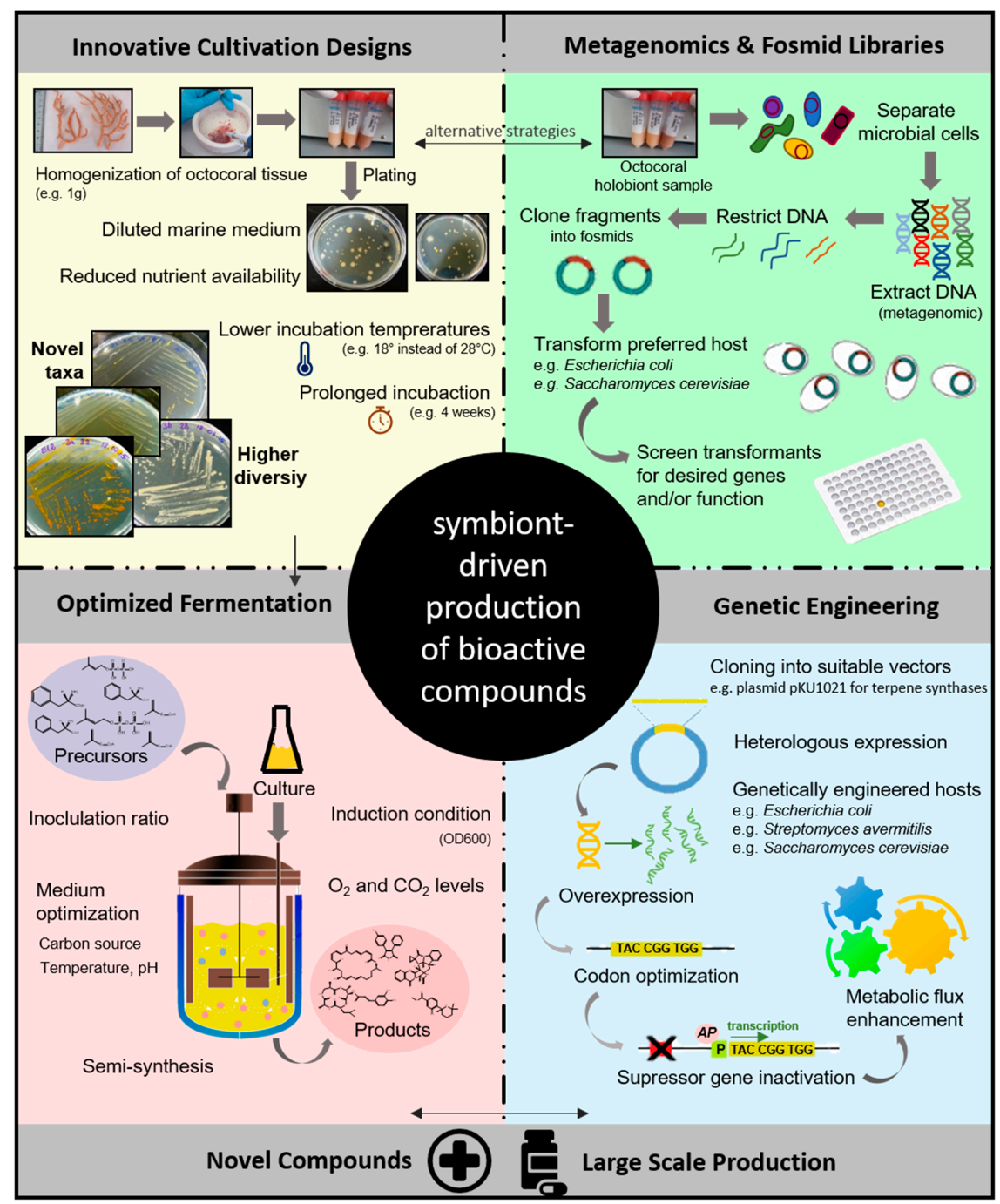

Figure 6. Optimal exploitation of the chemodiversity of octocoral-associated microbes. Schematic drawing illustrating important methodologies that need further development to widen the spectrum of bioactive natural products derived from octocoral-associated microorganisms and to optimize their production to meet industrial demands. Firstly, alternative cultivation approaches can increase the taxonomic and metabolic diversity of octocoral-associated microbes. Secondly, metagenomic tools and DNA-recombination technologies can provide access to valuable natural product biosynthetic gene clusters of often dominant symbionts recalcitrant to cultivation. Further, functional metagenomic studies can help to predict the symbionts' dietary needs, aiding in the formulation of improved cultivation media. Genetic engineering and heterologous expression systems can be used to significantly scale-up natural product outputs. The optimization of fermentation processes ultimately improves natural product titer, either in the native producer strain or in the heterologous host. 
Once a "bioactive" octocoral symbiont has been permanently and successfully brought into laboratory culture, the challenge is to improve natural product yield. Biosynthesis of the desired bioactive compound by the natural producer strain usually occurs at a rate that is much lower than what is required for industrialization. Titer improvement in native producing strains can often be achieved by the careful optimization of fermentation processes, which includes adjusting the type of growth medium and carbon source, the temperature, $\mathrm{pH}$, dissolved oxygen, and carbon dioxide levels. The inoculation ratio between the precursor substrate and carbon source and the inducer condition, i.e., inoculation time point and growth phase (OD600), are further important factors that require careful optimization [130]. In case that full fermentative processes are not economically viable or cannot be accomplished, semisynthetic strategies provide an alternative route in product development. Intermediate products are biologically synthesized before they are chemically converted to final products or, vice versa, a synthetic product is bio-converted using enzymes or fermentation processes into the end-product. For example, the $\beta$-lactam antibiotic cephalosporin $C$, derived from the marine ascomycete fungus Acremonium chrysogenum, was further developed by semi-synthesis into numerous commercial cephalosporin derivatives (e.g., cafalotin and cefazolin) with significantly increased antibiotic activity [127].

To meet the industrial demands of large-scale drug production, further genetic- and metabolic-engineering methodologies and strategies are often necessary. Frequently, the heterologous expression of the desired bioactive compound in genetically engineered microbial host cells, such as e.g., Escherichia coli or Saccharomyces cerevisiae, optimized for industrial-scale production, is preferred [130]. The synthase genes of interest are cloned into appropriate vectors which are then inserted into a suitable host cell to express the target genes. Diligent regulation of target gene expression using genetic approaches such as codon optimization and overexpression (e.g., through stronger promotors or transcriptional activators), as well as inactivation of repressor genes, have been very efficient in increasing natural-product titers [130]. A wide range of terpene synthases, for example, can be efficiently expressed in engineered Streptomyces avermitilis SUKA strains from which the native terpene synthase genes have been deleted. This way, the host is unable to produce endogenous terpenoid metabolites that could interfere with the production of heterologously expressed terpenoids. Streptomyces integrating plasmid vectors are used for the incorporation of genes encoding monoterpene, sesquiterpene, and diterpene synthases in S. avermitilis SUKA strains. Heterologous genes are inserted downstream of the appropriate synthase genes for precursor molecules, i.e., geranyl diphosphate synthase, farnesyl diphosphate synthase, or geranyl-geranyl diphosphate synthase under the control of a strong, constitutively expressed promoter (rpsJp) harbored in the integrating vector, e.g., pKU1021. The $S$. avermitilis SUKA system is suitable for the expression of a variety of terpenoid synthase genes from different bacterial phyla, including Gram-negative bacteria, and very useful for the discovery of new terpene synthases as well as the preparative isolation of terpenoid metabolites [13]. More examples of suitable heterologous expression systems and engineering strategies for optimized natural product production are given in the extensive reviews on microbial metabolic engineering and marine fungi biotechnology by Park et al. [130] and Silber et al. [127], respectively.

The combination of heterologous expression systems and modern metagenomics tools makes it possible that even the "pristine" resource of yet uncultivatable octocoral symbionts, be it bacteria, fungi, or other microeukaryotes, can be approached. Metagenomic libraries created via next generation-sequencing technologies give access to the total genomic pool of nature's microbiomes without the need of cultivation. In complex host-microbe systems, it bears great potential in the exploitation of the metabolism of often dominant bacterial symbionts recalcitrant to cultivation and to their concealed chemodiversity. High molecular-weight fragments of metagenomic DNA are ligated into fosmid, cosmid, or BAC vectors and, e.g., Escherichia coli transformants are then screened for a given bioactivity. So-called clone super-pooling strategies allow the efficient screening of 10,000 and more fosmid clones [131]. The combination of metagenomics and heterologous systems enables industrial-scale production of compounds never isolated and produced by so-far uncultivatable 
microorganisms [132]. Yet, despite the astonishing progress in molecular biology made in the last 20 years or so, the application of this technique in large-scale production of natural products is still scarce [49]. Most challenging is the complexity and size of the genetic clusters encoding for most natural products, and their intricate genetic regulation involving multiple regulatory cascades and networks [127]. Certainly, for marine microbial-derived natural products, the above-presented approaches are still in their infancy, yet investment in biotechnology development is the path for a sustainable production of octocoral- and other marine-derived microbial metabolites.

\section{Concluding Remarks}

This review demonstrates that the potential of octocoral-associated microbes to serve as prolific sources of novel natural products of interest in applied biotechnology is indisputable. However, much, if not all, of the chemodiversity known so far for these symbionts derives from bacterial and fungal cultures isolated in the laboratory. Still, many symbionts captured in culture have not been thoroughly explored in terms of their secondary metabolism and natural-product biosynthesis capacities. To this end, comprehensive genome mining coupled to laboratory experimentation needs to be applied for the already quite diverse panel of cultivatable octocoral symbionts, with apparently promising discoveries to be made if we are to mine the metabolism of cultivatable fungi and bacteria in depth. Quite clearly, it is imperative that we enlarge our analytical toolbox to integrate the wealth of recently developed metagenomics and next-generation sequencing technologies to the study of the complex microbiomes of octocorals. Although these approaches have been successfully implemented in biodiversity surveys, metagenomics-assisted investigation of natural product biosynthesis by uncultured octocoral symbionts awaits further development. Dedicated, cultivation-independent experiments hold promise in illuminating the metabolism of a wide diversity of not cultured or hitherto uncultivatable octocoral symbionts and, will be fundamental to allow the identification of microbial gene clusters involved in the biosynthesis of octocoral-derived metabolites in a comprehensive fashion. If coupled to heterologous expression systems fine-tuned to promote the biosynthesis of specific compounds (which is the case of existing terpenoid production platforms by surrogate bacterial hosts), metagenomics-guided metabolite biosynthesis by octocoral symbionts (from DNA extraction to recombination and expression) could become an alternative route to sustainably harvest novel natural products from lesser-known and hard-to-culture microorganisms. Such a multidisciplinary undertaken is key to achieving a sustainable response to the urgent industrial demand for novel drugs and enzyme varieties and can only be fostered through increased investment into next-generation biopharmaceuticals research and development, which considers well-grounded and environmentally reasonable exploitation of natural resources.

Supplementary Materials: The following files are available online at http:/ / www.mdpi.com/1660-3397/16/ 12/485/s1: Supplemental File S1. Biocatalysts from microbial symbionts of octocorals. Further information and literature on biocatalyst activities described for octocorals and their microbial associates, together with the genome mining results of 15 Eunicella spp.-derived bacterial genomes for the presence of BGCs (see also Table S2). The latter revealed a wealth of genes encoding for the biosynthesis of several important biocatalysts, from chitinases to cellulases, amylases, and a variety of proteases, Table S1. Bioactive natural products produced by octocoral associated microorganisms. Inventory of $>80$ bioactive compounds produced by bacteria and fungi associated with octocorals, Table S2. Copy number of open reading frames (ORFs) of biocatalyst protein families (PFAM) present on the genomes of 15 octocoral-associated bacteria.

Author Contributions: R.C. provided the reagents and materials. T.K.-C. and R.C. designed the study. I.R., S.G.S., and T.K.-C. performed literature research, analyzed the data, and prepared the figures and tables. I.R., S.G.S., and T.K.-C. wrote the first draft of the manuscript. T.K.-C. and R.C. wrote the final draft of the manuscript. All authors revised and commented on the manuscript and approved the submitted version.

Funding: This research was funded by the Portuguese Foundation for Science and Technology (FCT) through the research projects EXPL/MAR-EST/1664/2013 and PTDC/MAR-BIO/1547/2014; the APC was also funded by FCT [PTDC/MAR-BIO/1547/2014].

Acknowledgments: Jorge M.S. Gonçalves is kindly acknowledged for providing the underwater photograph of the octocoral Leptogorgia sarmentosa that is displayed in the graphical abstract. 
Conflicts of Interest: The authors declare no conflict of interest. The sponsors had no role in the design, execution, interpretation, or writing of the study.

\section{References}

1. Blunt, J.W.; Copp, B.R.; Keyzers, R.A.; Munroa, M.H.G.; Prinsep, M.R. Marine natural products. Nat. Prod. Rep. 2016, 33, 382-421. [CrossRef] [PubMed]

2. Look, S.A.; Fenical, W.; Robert, S.J.; Clardy, J. The Pseudopterosins: Anti-inflammatory and analgesic natural products from the sea whip Pseudopterogorgia elisabethae. Proc. Natl. Acad. Sci. USA 1986, 83, 6238-6240. [CrossRef] [PubMed]

3. Ospina, C.A.; Rodríguez, A.D.; Zhao, H.; Raptis, R.G. Bipinnapterolide B. a bioactive oxapolycyclic diterpene from the Colombian gorgonian coral Pseudopterogorgia bipinnata. Tetrahedron Lett. 2007, 48, 7520-7523. [CrossRef]

4. Ospina, C.A.; Rodríguez, A.D.; Sánchez, J.A.; Ortega-Barria, E.; Capson, T.L.; Mayer, A.M. Caucanolides A-F, unusual antiplasmodial constituents from a Colombian collection of the gorgonian coral Pseudopterogorgia bipinnata. J. Nat. Prod. 2005, 68, 1519-1526. [CrossRef] [PubMed]

5. Berrue, F.; Kerr, R.G. Diterpenes from gorgonian corals. Nat. Prod. Rep. 2009, 26, 681-710. [CrossRef] [PubMed]

6. Sheu, J.H.; Chen, Y.H.; Chen, Y.H.; Su, Y.D.; Chang, Y.C.; Su, J.H.; Weng, C.F.; Lee, C.H.; Fang, L.S.; Wang, W.H.; et al. Briarane diterpenoids isolated from gorgonian corals between 2011 and 2013. Mar. Drugs 2014, 12, 2164-2181. [CrossRef] [PubMed]

7. Rocha, J.; Peixe, L.; Gomes, N.C.M.; Calado, R. Cnidarians as a source of new marine bioactive compounds-An overview of the last decade and future steps for bioprospecting. Mar. Drugs 2011, 9, 1860-1886. [CrossRef]

8. Changyun, W.; Haiyan, L.; Changlun, S.; Yanan, W.; Liang, L.; Huashi, G. Chemical defensive substances of soft corals and gorgonians. Acta Ecol. Sin. 2008, 28, 2320-2328.

9. Berrue, F.; Withers, S.T.; Haltli, B.; Withers, J.; Kerr, R.G. Chemical screening method for the rapid identification of microbial sources of marine invertebrate-associated metabolites. Mar. Drugs 2011, 9, 369-381. [CrossRef]

10. Bhanot, A.; Sharma, R.; Noolvi, M.N. Natural sources as potential anti-cancer agents: A review. Int. J. Phytomed. 2011, 3, 9-26.

11. Piel, J.; Hui, D.Q.; Wen, G.P.; Butzke, D.; Platzer, M.; Fusetani, N.; Matsunaga, S. Antitumor polyketide biosynthesis by an uncultivated bacterial symbiont of the marine sponge Theonella swinhoei. Proc. Natl. Acad. Sci. USA 2004, 101, 16222-16227. [CrossRef] [PubMed]

12. Davidson, S.K.; Allen, S.W.; Lim, G.E.; Anderson, C.M.; Haygood, M.G. Evidence for the biosynthesis of Bryostatins by the bacterial symbiont "Candidatus Endobugula sertula" of the bryozoan Bugula neritina. Appl. Environ. Microbiol. 2001, 67, 4531-4537. [CrossRef] [PubMed]

13. Yamada, Y.; Kuzuyama, T.; Komatsu, M.; Shin-ya, K.; Omura, S.; Cane, D.E.; Ikeda, H. Terpene synthases are widely distributed in bacteria. Proc. Natl. Acad. Sci. USA 2015, 112, 857-862. [CrossRef] [PubMed]

14. Piel, J. A polyketide synthase-peptide synthetase gene cluster from an uncultured bacterial symbiont of Paederus beetles. Proc. Natl. Acad. Sci. USA 2002, 99, 14002-14007. [CrossRef] [PubMed]

15. Piel, J. Metabolites from symbiotic bacteria. Nat. Prod. Rep. 2004, 21, 519-538. [CrossRef] [PubMed]

16. Wilson, M.C.; Mori, T.; Rückert, C.; Uria, A.R.; Helf, M.J.; Takada, K.; Gernert, C.; Steffens, U.A.; Heycke, N.; Schmitt, S.; et al. An environmental bacterial taxon with a large and distinct metabolic repertoire. Nature 2014, 506, 58-62. [CrossRef] [PubMed]

17. Ebel, R. Terpenes from marine-derived fungi. Mar. Drugs 2010, 8, 2340-2368. [CrossRef] [PubMed]

18. Carvalho, C.C.C.R.; Fernandes, P. Production of metabolites as bacterial responses to the marine environment. Mar. Drugs 2010, 8, 705-727. [CrossRef] [PubMed]

19. Lopanik, N.; Lindquist, N.; Targett, N. Potent cytotoxins produced by a microbial symbiont protect host larvae from predation. Oecologia 2004, 139, 131-139. [CrossRef]

20. Kelman, D.; Kashman, Y.; Rosenberg, E.; Kushmaro, A.; Loya, Y. Antimicrobial activity of red sea corals. Mar. Biol. 2006, 149, 357-363. [CrossRef]

21. Wei, W.C.; Sung, P.J.; Duh, C.Y.; Chen, B.W.; Sheu, J.H.; Yang, N.S. Anti-inflammatory activities of natural products Isolated from soft corals of Taiwan between 2008 and 2012. Mar. Drugs 2013, 11, 4083-4126. [CrossRef] [PubMed] 
22. Van de Water, J.A.J.M.; Allemand, D.; Ferrier-Pagès, C. Host-microbe interactions in octocoral holobionts-Recent advances and perspectives. Microbiome 2018, 6. [CrossRef] [PubMed]

23. Blunt, J.W.; Carroll, A.R.; Copp, B.R.; Davis, R.A.; Keyzers, R.A.; Prinsep, M.R. Marine natural products. Nat. Prod. Rep. 2018, 35, 8-53. [CrossRef] [PubMed]

24. Blunt, J.W.; Copp, B.R.; Keyzers, R.A.; Munro, M.H.; Prinsep, M.R. Marine natural products. Nat. Prod. Rep. 2015, 32, 116-211. [CrossRef] [PubMed]

25. Blunt, J.W.; Copp, B.R.; Hu, W.P.; Munro, M.H.G.; Northcote, P.T.; Prinsep, M.R. Marine natural products. Nat. Prod. Rep. 2008, 25, 35-94. [CrossRef]

26. Blunt, J.W.; Copp, B.R.; Hu, W.P.; Munro, M.H.G.; Northcote, P.T.; Prinsep, M.R. Marine natural products. Nat. Prod. Rep. 2009, 26, 170-244. [CrossRef] [PubMed]

27. Blunt, J.W.; Copp, B.R.; Keyzers, R.A.; Munro, M.H.G.; Prinsep, M.R. Marine natural products. Nat. Prod. Rep. 2017, 34, 235-294. [CrossRef] [PubMed]

28. Blunt, J.W.; Copp, B.R.; Keyzers, R.A.; Munro, M.H.G.; Prinsep, M.R. Marine natural products. Nat. Prod. Rep. 2014, 31, 160-258. [CrossRef]

29. Blunt, J.W.; Copp, B.R.; Keyzers, R.A.; Munro, M.H.G.; Prinsep, M.R. Marine natural products. Nat. Prod. Rep. 2013, 30, 237-323. [CrossRef]

30. Blunt, J.W.; Copp, B.R.; Keyzers, R.A.; Munro, M.H.G.; Prinsep, M.R. Marine natural products. Nat. Prod. Rep. 2012, 29, 144-222. [CrossRef]

31. Blunt, J.W.; Copp, B.R.; Munro, M.H.G.; Northcote, P.T.; Prinsep, M.R. Marine natural products. Nat. Prod. Rep. 2011, 28, 196-268. [CrossRef] [PubMed]

32. Blunt, J.W.; Copp, B.R.; Munro, M.H.G.; Northcote, P.T.; Prinsep, M.R. Marine natural products. Nat. Prod. Rep. 2010, 27, 165-237. [CrossRef] [PubMed]

33. Bourne, D.G.; Morrow, K.M.; Webster, N.S. Insights into the coral microbiome: Underpinning the health and resilience of reef ecosystems. Annu. Rev. Microbiol. 2016, 70, 317-340. [CrossRef] [PubMed]

34. Rosenberg, E.; Koren, O.; Reshef, L.; Efrony, R.; Zilber-Rosenberg, I. The role of microorganisms in coral health, disease and evolution. Nat. Rev. Microbiol. 2007, 5, 355-362. [CrossRef] [PubMed]

35. Peixoto, R.S.; Rosado, P.M.; Leite, D.C.A.; Rosado, A.S.; Bourne, D.G. Beneficial microorganisms for corals (BMC): Proposed mechanisms for coral health and resilience. Front. Microbiol. 2017, 8, 1-16. [CrossRef] [PubMed]

36. Daly, M.; Brugler, M.R.; Cartwright, P.; Collins, A.G.; Dawson, M.N.; Fautin, D.G.; France, S.C.; McFadden, C.S.; Opresko, D.M.; Rodriquez, E.; et al. The phylum Cnidaria: A review of phylogenetic patterns and diversity 300 years after Linnaeus. Zootaxa 2007, 1668, 127-182.

37. Gili, J.M.; Garcia, A. Biologia de Paramuricea clavata a les costes catalanes generals. Bull. Inst. Cato Hist. Nat. 1985, 52, 25-32.

38. Curdia, J.; Monteiro, P.; Afonso, C.M.L.; Santos, M.N.; Cunha, M.R.; Goncalves, J.M.S. Spatial and depth-associated distribution patterns of shallow gorgonians in the Algarve coast (Portugal, NE Atlantic). Helgol. Mar. Res. 2013, 67, 521-534. [CrossRef]

39. Gili, J.M.; Coma, R. Benthic suspension feeders: Their paramount role in littoral marine food webs. Trends Ecol. Evolution. 1998, 13, 316-321. [CrossRef]

40. Cerrano, C.; Danovaro, R.; Gambi, C.; Pusceddu, A.; Riva, A.; Schiaparelli, S. Gold coral (Savalia savaglia) and gorgonian forests enhance benthic biodiversity and ecosystem functioning in the mesophotic zone. Biodivers. Conserv. 2010, 19, 153-167. [CrossRef]

41. Raina, J.B.; Tapiolas, D.; Willis, B.L.; Bourne, D.G. Coral-associated bacteria and their role in the biogeochemical cycling of sulfur. Appl. Environ. Microbiol. 2009, 75, 3492-3501. [CrossRef] [PubMed]

42. Ransome, E.; Rowley, S.J.; Thomas, S.; Tait, K.; Munn, C.B. Disturbance to conserved bacterial communities in the cold-water gorgonian coral Eunicella verrucosa. FEMS Microbiol. Ecol. 2014, 90, 404-416. [CrossRef] [PubMed]

43. Gori, A.; Bramanti, L.; Lopez-Gonzalez, P.; Thoma, J.N.; Gili, J.M.; Grinyo, J.; Uceira, V.; Rossi, S. Characterization of the zooxanthellate and azooxanthellate morphotypes of the Mediterranean gorgonian Eunicella singularis. Mar. Biol. 2012, 159, 1485-1496. [CrossRef]

44. Keller-Costa, T.; Eriksson, D.; Gonçalves, J.M.S.; Gomes, N.C.M.; Lago-Leston, A.; Costa, R. The gorgonian coral Eunicella labiata hosts a distinct prokaryotic consortium amenable to cultivation. FEMS Microbiol. Ecol. 2017, 93, 1-19. [CrossRef] [PubMed] 
45. Bayer, T.; Arif, C.; Ferrier-Pages, C.; Zoccola, D.; Aranda, M.; Voolstra, C.R. Bacteria of the genus Endozoicomonas dominate the microbiome of the Mediterranean gorgonian coral Eunicella cavolini. Mar. Ecol. Prog. Ser. 2013, 479, 75-84. [CrossRef]

46. La Riviere, M.; Roumagnac, M.; Garrabou, J.; Bally, M. Transient shifts in bacterial communities associated with the temperate gorgonian Paramuricea clavata in the Northwestern Mediterranean Sea. PLoS ONE 2013, 8. [CrossRef] [PubMed]

47. Van de Water, J.A.J.M.; Melkonian, R.; Junca, H.; Voolstra, C.R.; Reynaud, S.; Allemand, D.; Ferrier-Pagès, C. Spirochaetes dominate the microbial community associated with the red coral Corallium rubrum on a broad geographic scale. Sci. Rep. 2016, 6, 27277. [CrossRef] [PubMed]

48. Rath, C.; Janto, B.; Earl, J.; Ahmed, A.; Hu, F.Z.; Hiller, L.; Dahlgren, M.; Kreft, R.; Yu, F.; Wolff, J.J.; et al. Meta-omic characterization of the marine invertebrate microbial consortium that produces the chemotherapeutic natural product ET-743. ACS Chem. Biol. 2011, 6, 1244-1256. [CrossRef]

49. Trindade, M.; van Zyl, L.J.; Navarro-Fernández, J.; Elrazak, A.A. Targeted metagenomics as a tool to tap into marine natural product diversity for the discovery and production of drug candidates. Front. Microbiol. 2015, 6, 890. [CrossRef]

50. Barrero-Canosa, J.; Dueñas, L.F.; Sánchez, J.A. Isolation of potential fungal pathogens in gorgonian corals at the Tropical Eastern Pacific. Coral Reefs 2013, 32, 35-41. [CrossRef]

51. Zhang, X.-Y.; Bao, J.; Wang, G.-H.; He, F.; Xu, X.-Y.; Qi, S.-H. Diversity and antimicrobial activity of culturable fungi isolated from six species of the South China Sea gorgonians. Microb. Ecol. 2012, 64, 617-627. [CrossRef] [PubMed]

52. Soler-Hurtado, M.M.; Sandoval-Sierra, J.V.; Annie Machordom, A.; DieÂguez-Uribeondo, J. Aspergillus sydowii and other potential fungal pathogens in gorgonian octocorals of the Ecuadorian Pacific. PLoS ONE 2016, 11, e0165992. [CrossRef] [PubMed]

53. Singer, A.C.; Shaw, H.; Rhodes, V.; Hart, A. Review of antimicrobial resistance in the environment and its relevance to environmental regulators. Front. Microbiol. 2016, 7, 1728. [CrossRef] [PubMed]

54. Klein, E.; Smith, D.L.; Laxminarayan, R. Hospitalizations and deaths caused by methicillin-resistant Staphylococcus aureus. Emerg. Infect. Dis. 2007, 13, 1840-1846. [CrossRef] [PubMed]

55. Boswihi, S.S.; Udo, E.E. Methicillin-resistant Staphylococcus aureus: An update on the epidemiology, treatment options and infection control. Curr. Med. Res. Pract. 2018, 8, 18-24. [CrossRef]

56. Moree, W.J.; McConnell, O.J.; Nguyen, D.D.; Sanchez, L.M.; Yang, Y.-L.; Zhao, X.; Liu, W.-T.; Boudreau, P.D.; Srinivasan, J.; Atencio, L.; et al. Microbiota of healthy corals are active against fungi in a light-dependent manner. ACS Chem. Biol. 2014, 9, 2300-2308. [CrossRef] [PubMed]

57. Shigemori, H.; Bae, M.-A.; Yazawa, K.; Sasaki, T.; Kobayashi, J. Alteramide A, a new tetracyclic alkaloid from a bacterium Alteromonas sp. associated with the marine sponge Ealhhondria okadai. J. Organ. Chem. 1992, 57, 4317-4320. [CrossRef]

58. Gao, C.-H.; Tian, X.-P.; Qi, S.-H.; Luo, X.-M.; Wang, P.; Zhang, S. Antibacterial and antilarval compounds from marine gorgonian-associated bacterium Bacillus amyloliquefaciens SCSIO 00856. J. Antibiot. 2010, 63, 191-193. [CrossRef] [PubMed]

59. Al-Zereini, W.; Yao, B.C.F.F.; Laatsch, H.; Anke, H. Aqabamycins A-G: Novel nitro maleimides from a marine Vibrio species: I. Taxonomy, fermentation, isolation and biological activities. J. Antibiot. 2010, 63, $297-301$. [CrossRef]

60. Sulistiyani, S.; Nugraheni, S.A.; Radjasa, O.K.; Sabdono, A.; Khoeri, M.M. Antibacterial activities of bacterial symbionts of soft coral Sinularia sp. against tuberculosis bacteria. J. Coast. Dev. 2010, 14, 45-50.

61. Radjasa, O.K.; Sabdono, A. Ecological role of a soft coral-associated bacterium Arthrobacter sp. on marine biofilm-forming bacteria. Microbiol. Indones. 2008, 2, 84-88.

62. Zheng, C.J.; Shao, C.L.; Wu, L.Y.; Chen, M.; Wang, K.L.; Zhao, D.L.; Sun, X.P.; Chen, G.Y.; Wang, C.Y. Bioactive phenylalanine derivatives and cytochalasins from the soft coral-derived fungus, Aspergillus elegans. Mar. Drugs 2013, 11, 2054-2068. [CrossRef] [PubMed]

63. Mack, D.; Davies, A.P.; Harris, L.G.; Jeeves, R.; Pascoe, B.; Knobloch, J.K.M.; Rohde, H.; Wilkinson, T.S. Staphylococcus epidermidis in biomaterial-associated infections. In Biomaterials Associated Infection: Immunological Aspects and Antimicrobial Strategies; Moriarty, T.F., Zaat, S.A.J., Busscher, H.J., Eds.; Springer Science + Business Media: New York, NY, USA, 2013; pp. 25-56. 
64. Chen, M.; Fu, X.M.; Kong, C.J.; Wang, C.Y. Nucleoside derivatives from the marine-derived fungus Aspergillus versicolor. Nat. Prod. Res. 2014, 28, 895-900. [CrossRef] [PubMed]

65. Chen, M.; Shao, C.L.; Fu, X.M.; Kong, C.J.; She, Z.G.; Wang, C.Y. Lumazine peptides penilumamides B-D and the cyclic pentapeptide asperpeptide A from a gorgonian-derived Aspergillus sp. fungus. J. Nat. Prod. 2014, 77, 1601-1606. [CrossRef]

66. Wei, M.Y.; Wang, C.Y.; Liu, Q.A.; Shao, C.L.; She, Z.G.; Lin, Y.C. Five sesquiterpenoids from a marine-derived fungus Aspergillus sp. isolated from a gorgonian Dichotella gemmacea. Mar. Drugs 2010, 8, 941-949. [CrossRef]

67. Khamthong, N.; Rukachaisirikul, V.; Phongpaichit, S.; Preedanon, S.; Sakayaroj, J. Bioactive polyketides from the sea fan-derived fungus Penicillium citrinum PSU-F51. Tetrahedron 2010, 68, 8245-8250. [CrossRef]

68. Wang, J.; Liu, P.; Wang, Y.; Wang, H.; Li, J.; Zhuang, Y.; Zhu, W. Antimicrobial aromatic polyketides from gorgonian-associated fungus, Penicillium commune 518. Chin. J. Chem. 2012, 30, 1236-1242. [CrossRef]

69. Wei, M.Y.; Li, D.; Shao, C.L.; Deng, D.S.; Wang, C.Y. ( \pm )-Pestalachloride D, an antibacterial racemate of chlorinated benzophenone derivative from a soft coral-derived fungus Pestalotiopsis sp. Mar. Drugs 2013,11, 1050-1060. [CrossRef]

70. Zhuang, Y.; Teng, X.; Wang, Y.; Liu, P.; Wang, H.; Li, J.; Li, G.; Zhu, W. Cyclopeptides and polyketides from coral-associated fungus, Aspergillus versicolor LCJ-5-4. Tetrahedron 2011, 67, 7085-7089. [CrossRef]

71. Zhuang, Y.; Teng, X.; Wang, Y.; Liu, P.; Li, G.; Zhu, W. New quinazolinone alkaloids within rare amino acid residue from coral- associated fungus, Aspergillus versicolor LCJ-5-4. Organ. Lett. 2011, 13, 1130-1133. [CrossRef]

72. Satheesh, S.; Ba-akdah, M.A.; Al-Sofyani, A.A. Natural antifouling compound production by microbes associated with marine macroorganisms-A review. Electron. J. Biotechnol. 2016, 21, 26-35. [CrossRef]

73. Antizar-Ladislao, B. Environmental levels, toxicity and human exposure to tributyltin (TBT)-contaminated marine environment. A review. Environ. Int. 2008, 34, 292-308. [CrossRef] [PubMed]

74. Qian, P.-Y.; Li, Z.; Xu, Y.; Li, Y.; Fusetani, N. Mini-review: Marine natural products and their synthetic analogs as antifouling compounds: 2009-2014. Biofouling 2015, 31, 101-122. [CrossRef] [PubMed]

75. Qi, S.-H.; Ma, X. Antifouling Compounds from Marine Invertebrates. Mar. Drugs 2017, 15, 263. [CrossRef]

76. Dobretsov, S.; Qian, P.-Y. The role of epibotic bacteria from the surface of the soft coral Dendronephthya sp. in the inhibition of larval settlement. J. Exp. Mar. Biol. Ecol. 2004, 299, 35-50. [CrossRef]

77. Shao, C.L.; Wu, H.X.; Wang, C.Y.; Liu, Q.A.; Xu, Y.; Wei, M.Y.; Qian, P.Y.; Gu, Y.C.; Zheng, C.J.; She, Z.G.; et al. Potent antifouling resorcylic acid lactones from the gorgonian-derived fungus Cochliobolus lunatus. J. Nat. Prod. 2011, 74, 629-633. [CrossRef]

78. Bao, J.; Sun, Y.-L.; Zhang, X.-Y.; Han, Z.; Gao, H.-C.; He, F.; Qian, P.-Y.; Qi, S.-H. Antifouling and antibacterial polyketides from marine gorgonian coral-associated fungus Penicillium sp. SCSGAF 0023. J. Antibiot. 2012, 66, 219. [CrossRef]

79. Bao, J.; Zhang, X.-Y.; Xu, X.-Y.; He, F.; Nong, X.-H.; Qi, S.-H. New cyclic tetrapeptides and asteltoxins from gorgonian-derived fungus Aspergillus sp. SCSGAF 0076. Tetrahedron 2013, 69, 2113-2117. [CrossRef]

80. He, F.; Han, Z.; Peng, J.; Qian, P.-Y.; Qi, S.-H. Antifouling indole alkaloids from two marine derived fungi. Nat. Prod. Commun. 2013, 8, 329-332.

81. Cheung, R.C.; Wong, J.H.; Pan, W.L.; Chan, Y.S.; Yin, C.M.; Dan, X.L.; Wang, H.X.; Fang, E.F.; Lam, S.K.; Ngai, P.H.; et al. Antifungal and antiviral products of marine organisms. Appl. Microbiol. Biotechnol. 2014, 98, 3475-3494. [CrossRef]

82. Moghadamtousi, S.Z.; Nikzad, S.; Kadir, H.A.; Abubakar, S.; Keivan Zandi, K. Potential antiviral agents from marine fungi: An overview. Mar. Drugs 2015, 13, 4520-4538. [CrossRef] [PubMed]

83. Chen, M.; Shao, C.L.; Meng, H.; She, Z.G.; Wang, C.Y. Anti-respiratory syncytial virus prenylated dihydroquinolone derivatives from the gorgonian-derived fungus Aspergillus sp. XS-20090B15. J. Nat. Prod. 2014, 77, 2720-2724. [CrossRef] [PubMed]

84. He, F.; Bao, J.; Zhang, X.-Y.; Tu, Z.-C.; Shi, Y.-M.; Qi, S.-H. Asperterrestide A, a cytotoxic cyclic tetrapeptide from the marine-derived fungus Aspergillus terreus SCSGAF0162. J. Nat. Prod. 2013, 76, 1182-1186. [CrossRef] [PubMed]

85. Bao, J.; Xu, X.-Y.; Zhang, X.-Y.; Qi, S.-H. A new macrolide from a marine-derived fungus Aspergillus sp. Nat. Prod. Commun. 2013, 8, 1127-1128. [PubMed]

86. Nong, X.H.; Wang, Y.F.; Zhang, X.Y.; Zhou, M.P.; Xu, X.Y.; Qi, S.H. Territrem and butyrolactone derivatives from a marine-derived fungus Aspergillus terreus. Mar. Drugs 2014, 12, 6113-6124. [CrossRef] [PubMed] 
87. Zheng, C.-J.; Shao, C.-L.; Guo, Z.-Y.; Chen, J.-F.; Deng, D.-S.; Yang, K.-L.; Chen, Y.-Y.; Fu, X.-M.; She, Z.-G.; Lin, Y.-C.; et al. Bioactive hydroanthraquinones and anthraquinone dimers from a soft coral-derived Alternaria sp. fungus. J. Nat. Prod. 2012, 75, 189-197. [CrossRef] [PubMed]

88. Jia, Y.-L.; Wei, M.-Y.; Chen, H.-Y.; Guan, F.-F.; Wang, C.-Y.; Shao, C.-L. (+)- and (-)-Pestaloxazine A, a pair of antiviral enantiomeric alkaloid dimers with a symmetric spiro [oxazinane-piperazinedione] skeleton from Pestalotiopsis sp. Organ. Lett. 2015, 17, 4216-4219. [CrossRef] [PubMed]

89. Ruiz-Torres, V.; Encinar, J.A.; Herranz-López, M.; Pérez-Sánchez, A.; Galiano, V.; Barrajón-Catalán, E.; Micol, V. An updated review on marine anticancer compounds: The use of virtual screening for the discovery of small-molecule cancer drugs. Molecules 2017, 22, 1037. [CrossRef]

90. Grote, D.; Hänel, F.; Dahse, H.M.; Seifert, K. Capnellenes from the soft coral Dendronephthya rubeola. Chem. Biodivers. 2008, 5, 1683-1693. [CrossRef]

91. Marrero, J.; Rodríguez, A.D.; Baran, P.; Raptis, R.G.; Sánchez, J.A.; Ortega-Barria, E.; Capson, T.L. Bielschowskysin, a gorgonian-derived biologically active diterpene with an unprecedented carbon skeleton. Organ. Lett. 2004, 6, 1661-1664. [CrossRef]

92. Duh, C.Y.; El-Gamal, A.A.H.; Chu, C.J.; Wang, S.K.; Dai, C.F. New cytotoxic constituents from the Formosan soft corals Clavularia viridis and Clavularia violacea. J. Nat. Prod. 2002, 65, 1535-1539. [CrossRef] [PubMed]

93. Shen, Y.C.; Cheng, Y.B.; Lin, Y.C.; Guh, J.H.; Teng, C.M.; Ko, C.L. New prostanoids with cytotoxic activity from Taiwanese octocoral Clavularia viridis. J. Nat. Prod. 2004, 67, 542-546. [CrossRef] [PubMed]

94. Chao, C.-H.; Huang, L.-F.; Yang, Y.-L.; Su, J.-H.; Wang, G.-H.; Chiang, M.-Y.; Wu, Y.-C.; Dai, C.-F.; Sheu, J.H. Polyoxygenated steroids from the gorgonian Isis hippuris. J. Nat. Prod. 2005, 68, 880-885. [CrossRef] [PubMed]

95. Chen, B.W.; Wu, Y.C.; Chiang, M.-Y.; Su, J.-H.; Wang, W.H.; Fan, T.-Y.; Sheu, J.H. Eunicellin-based diterpenoids from the cultured soft coral Klyxum simplex. Tetrahedron 2009, 65, 7016-7022. [CrossRef]

96. Fu, P.; Kong, F.; Wang, Y.; Wang, Y.; Liu, P.; Zuo, G.; Zhu, W. Antibiotic metabolites from the coral-associated actinomycete Streptomyces sp. OUCMDZ-1703. Chin. J. Chem. 2013, 31, 100-104. [CrossRef]

97. Chen, Y.-H.; Lu, M.-C.; Chang, Y.-C.; Hwang, T.-L.; Wang, W.H.; Weng, C.F.; Kuo, J.; Sung, P.J. Pseudoalteromone A: A novel bioactive ubiquinone from a marine bacterium Pseudoalteromonas sp. CGH2XX (Pseudoalteromonadaceae). Tetrahedron Lett. 2012, 53, 1675-1677. [CrossRef]

98. Li, H.-J.; Jiang, W.-H.; Liang, W.-L.; Huang, J.-X.; Mo, Y.-F.; Ding, Y.-Q.; Lam, C.-K.; Qian, X.-J.; Zhu, X.-Z.; Lan, W.-J. Induced marine fungus Chondrostereum sp. as a means of producing new sesquiterpenoids chondrosterins I and J by using glycerol as the carbon source. Mar. Drugs 2014, 12, 167-175. [CrossRef]

99. Li, H.-J.; Xie, Y.-L.; Xie, Z.-L.; Chen, Y.; Lam, C.-K.; Lan, W.-J. Chondrosterins A-E, triquinane-type sesquiterpenoids from soft coral-associated fungus Chondrostereum sp. Mar. Drugs 2012, 10, 627-638. [CrossRef]

100. Li, H.-J.; Chen, T.; Xie, Y.-L.; Chen, W.-D.; Zhu, X.-F.; Lan, W.-J. Isolation and structural elucidation of chondrosterins F-H from the marine fungus Chondrostereum sp. Mar. Drugs 2013, 11, 551-558. [CrossRef]

101. Li, H.-J.; Lan, W.-J.; Lam, C.-K.; Yang, F.; Zhu, X.-F. Hirsutane sesquiterpenoids from the marine-derived fungus Chondrostereum sp. Chem. Biodivers. 2011, 8, 317-324. [CrossRef]

102. Shao, C.-L.; Wanga, C.-Y.; Wei, M.-Y.; Gu, Y.-C.; She, Z.-G.; Qian, P.-Y.; Lin, Y.-C. Aspergilones A and B, two benzylazaphilones with an unprecedented carbon skeleton from the gorgonian-derived fungus Aspergillus sp. Bioorgan. Med. Chem. Lett. 2011, 21, 690-693. [CrossRef] [PubMed]

103. Sun, Y.-L.; Bao, J.; Liu, K.-S.; Zhang, X.-Y.; He, F.; Wang, Y.F.; Nong, X.-H.; Qi, S.-H. Cytotoxic dihydrothiophene-condensed chromones from the marine-derived fungus Penicillium oxalicum. Planta Med. 2013, 79, 1474-1479. [CrossRef] [PubMed]

104. Kasettrathat, C.; Ngamrojanavanich, N.; Wiyakrutta, S.; Mahidol, C.; Ruchirawat, S.; Kittakoop, P. Cytotoxic and antiplasmodial substances from marine-derived fungi, Nodulisporium sp. and CRI247-01. Phytochemistry 2008, 69, 2621-2626. [CrossRef] [PubMed]

105. Mayer, A.M.S.; Glaser, K.B.; Cuevas, C.; Jacobs, R.S.; Kem, W.; Little, R.D.; McIntosh, J.M.; Newman, D.J.; Potts, B.C.; Shuster, D.E. The odyssey of marine pharmaceuticals: A current pipeline perspective. Trends Pharmacol. Sci. 2010, 31, 255-265. [CrossRef] [PubMed]

106. Mydlarz, L.D.; Jacobs, R.S.; Boehnlein, J.; Kerr, R.G. Pseudopterosin biosynthesis in Symbiodinium sp., the dinoflagellate symbiont of Pseudopterogorgia elisabethae. Chem. Biol. 2003, 10, 1051-1056. [CrossRef] [PubMed] 
107. Hofseth, L.J. Nitric oxide as a target of complementary and alternative medicines to prevent and treat inflammation and cancer. Cancer Lett. 2008, 268, 10-30. [CrossRef] [PubMed]

108. Liu, M.; Zhou, Q.; Wang, J.; Liu, J.; Qi, C.; Lai, Y.; Zhu, H.; Xue, Y.; Hu, Z.; Zhang, Y. Anti-inflammatory butenolide derivatives from the coral-derived fungus Aspergillus terreus and structure revisions of aspernolides D and G, butyrolactone VI and $4^{\prime}, 8^{\prime \prime}$-diacetoxy butyrolactone VI. RSC Adv. 2018, 8, 13040-13047. [CrossRef]

109. Wei, M.-Y.; Chen, G.-Y.; Wang, Y.; Zhang, X.-L.; Wang, C.-Y.; Shao, C.-L. Isolation, 1H, 13C NMR assignments, and crystal structure of chrodrimanin B from a marine fungus Aspergillus sp. Chem. Nat. Compd. 2011, 47, 571-573. [CrossRef]

110. Xu, Y.; Furutani, S.; Ihara, M.; Ling, Y.; Yang, X.; Kai, K.; Hayashi, H.; Matsuda, K. Meroterpenoid chrodrimanins are selective and potent blockers of insect GABA-gated chloride channels. PLoS ONE 2015, 10, e0122629. [CrossRef] [PubMed]

111. Afiyatullov, S.S.; Zhuravleva, O.I.; Chaikina, E.L.; Anisimov, M.M. A new spirotryprostatin from the marine isolate of the fungus Aspergillus fumigatus. Chem. Nat. Compd. 2012, 48. [CrossRef]

112. Martin, Y.; Bonnefort, J.L.; Chancerelle, L. Gorgonians mass mortality during the 1999 late summer in French Mediterranean coastal waters: The bacterial hypothesis. Water Res. 2002, 36, 779-782. [CrossRef]

113. Hall-Spencer, J.M.; Pike, J.; Munn, C.B. Diseases affect cold-water corals too: Eunicella verrucosa (Cnidaria: Gorgonacea) necrosis in SW England. Dis. Aquatic Organ. 2007, 76, 87-97. [CrossRef] [PubMed]

114. Vezzulli, L.; Previati, M.; Pruzzo, C.; Marchese, A.; Bourne, D.G.; Cerrano, C.; VibrioSea, C. Vibrio infections triggering mass mortality events in a warming Mediterranean Sea. Environ. Microbiol. 2010, 12, 2007-2019. [CrossRef] [PubMed]

115. Roussis, V.; Fenical, W.; Vagias, C.; Kornprobst, J.M.; Miralles, J. Labiatamides A, B, and other eunicellan diterpenoids from the Senegalese gorgonian Eunicella labiata. Tetrahedron 1996, 52, 2735-2742. [CrossRef]

116. Keller-Costa, T.; Silva, R.; Lago-Lestón, A.; Costa, R. Genomic insights into Aquimarina sp. EL33, a bacterial symbiont of the gorgonian coral Eunicella labiata. Genome Announc. 2016, 4, e00855-16. [CrossRef] [PubMed]

117. Silva, S.G.; Lago-Lestón, A.; Costa, R.; Keller-Costa, T. Draft genome sequence of Sphingorhabdus sp. strain EL138, a metabolically-versatile alphaproteobacterium isolated from the gorgonian coral Eunicella labiata. Genome Announc. 2018, 6, e00142-18. [CrossRef] [PubMed]

118. Rodrigues, G.N.; Lago-Lestón, A.; Costa, R.; Keller-Costa, T. Draft genome sequence of Labrenzia sp. strain EL143, a coral-associated alphaproteobacterium with versatile symbiotic living capability and strong halogen degradation potential. Genome Announc. 2018, 6, e00132-18. [CrossRef] [PubMed]

119. Weber, T.; Blin, K.; Duddela, S.; Krug, D.; Kim, H.U.; Bruccoleri, R.; Lee, S.Y.; Fischbach, M.A.; Müller, R.; Wohlleben, W.; et al. AntiSMASH 3.0-A comprehensive resource for the genome mining of biosynthetic gene clusters. Nucleic Acids Res. 2015, 43, W237-W243. [CrossRef] [PubMed]

120. Franco, T.; Califano, G.; Gonçalves, A.C.; Cúcio, C.; Costa, R. Draft genome sequence of Vibrio sp. strain Evh12, a bacterium retrieved from the gorgonian coral Eunicella verrucosa. Genome Announc. 2016, 4, e01729-15. [CrossRef] [PubMed]

121. Cúcio, A.C. Molecular Exploration of Bacterial Communities Associated with Azooxanthellate Gorgonians in the Coast of Algarve, South Portugal; University of Algarve: Faro, Portugal, 2012.

122. Ambati, R.R.; Phang, S.M.; Ravi, S.; Aswathanarayana, R.G. Astaxanthin: Sources, extraction, stability, biological activities and its commercial applications-A review. Mar. Drugs 2014, 12, 128. [CrossRef]

123. Lucas-Elío, P.; Gómez, D.; Solano, F.; Sanchez-Amat, A. The antimicrobial activity of marinocine, synthesized by Marinomonas mediterranea, is due to hydrogen peroxide generated by its lysine oxidase activity. J. Bacteriol. 2006, 188, 2493-2501. [CrossRef] [PubMed]

124. Sun, W.; Peng, C.; Zhao, Y.; Li, Z. Functional gene-guided discovery of type II polyketides from culturable Actinomycetes associated with soft coral Scleronephthya sp. PLoS ONE 2012, 7, e42847. [CrossRef] [PubMed]

125. Jakeman, D.L.; Bandi, S.; Graham, C.L.; Reid, T.R.; Wentzell, J.R.; Douglas, S.E. Antimicrobial activities of jadomycin B and structurally related analogues. Antimicrob. Agents Chemother. 2009, 53, 1245-1247. [CrossRef] [PubMed]

126. Trincone, A. Marine biocatalysts: Enzymatic features and applications. Mar. Drugs 2011, 9, 478-499. [CrossRef] [PubMed]

127. Silber, J.; Kramer, A.; Labes, A.; Tasdemir, D. From discovery to production: Biotechnology of marine fungi for the production of new antibiotics. Mar. Drugs 2016, 14, 137. [CrossRef] [PubMed] 
128. Parente, R.; Feola, V.C.; Gimigliano, A. R\&D management in the pharma industry: The strategic role of CROs. Sinerg. Ital. J. Manag. 2016, 34. [CrossRef]

129. Pattnaik, P.; Pandey, S.C. University spinoffs: What, why, and how? Technol. Innov. Manag. Rev. 2014, 4, 44-50. [CrossRef]

130. Park, S.Y.; Yang, D.; Ha, S.H.; Lee, S.Y. Metabolic engineering of microorganisms for the production of natural compounds. Adv. Biosyst. 2018, 2, 1700190. [CrossRef]

131. Hjort, K.; Bergström, M.; Adesina, M.F.; Jansson, J.K.; Smalla, K.; Sjöling, S. Chitinase genes revealed and compared in bacterial isolates, DNA-extracts and a metagenomic library from a phytopathogen-suppressive soil. FEMS Microbiol. Ecol. 2010, 71, 197-207. [CrossRef]

132. Van Elsas, J.D.; Costa, R.; Jansson, J.; Sjöling, S.; Bailey, M.; Nalin, R.; Vogel, T.M.; van Overbeek, L. The metagenomics of disease-suppressive soils-Experiences from the METACONTROL project. Trends Biotechnol. 2008, 26, 591-601. [CrossRef]

(C) 2018 by the authors. Licensee MDPI, Basel, Switzerland. This article is an open access article distributed under the terms and conditions of the Creative Commons Attribution (CC BY) license (http://creativecommons.org/licenses/by/4.0/). 